\title{
A Risk Score to Predict Admission to Intensive Care Unit in Patients With COVID-19: The ABC-GOALS Score
}

Juan M. Mejía-Vilet, MD, MSc. ${ }^{1}$

Bertha M. Córdova-Sánchez, MD, MSc ${ }^{2}$

Dheni A. Fernández-Camargo, MD ${ }^{1}$

R. Angélica Méndez-Pérez, MD ${ }^{1}$

Luis E. Morales Buenrostro, MD, PhD ${ }^{1}$

Thierry Hernández-Gilsoul, MD, MSc ${ }^{3}$

${ }^{1}$ Department of Nephrology and Mineral Metabolism, Instituto Nacional de Ciencias Médicas y Nutrición Salvador Zubirán, Mexico City, Mexico

${ }^{2}$ Department of Critical Care Medicine, Instituto Nacional de Cancerología, Mexico City, Mexico

3 Emergency Department, Instituto Nacional de Ciencias Médicas y Nutrición Salvador Zubirán, Mexico City, Mexico

\section{Correspondence:}

Thierry Hernández-Gilsoul

Head of the Emergency Department, Instituto Nacional de Ciencias Médicas y

Nutrición Salvador Zubirán, Mexico City, Mexico

Vasco de Quiroga 15, Belisario Domínguez Sección XVI, Tlalpan, Mexico City,

Mexico, 14080

Email: thierry.hernandezg@incmnsz.mx, Phone: +52 5554870900 Extension 5067

Running Title: ABC-GOALS score to predict ICU admission

Keywords: $\quad$ COVID-19, coronavirus, prediction, intensive care unit. 
medRxiv preprint doi: https://doi.org/10.1101/2020.05.12.20099416; this version posted May 30, 2020. The copyright holder for this preprint

(which was not certified by peer review) is the author/funder, who has granted medRxiv a license to display the preprint in perpetuity.

It is made available under a CC-BY-NC-ND 4.0 International license .

\section{ABSTRACT}

Objectives. COVID-19 pandemic poses a burden on hospital resources and intensive care unit (ICU) occupation. This study aimed to provide a scoring system that, assessed upon first-contact evaluation at the emergency department, predicts the need for ICU admission.

Methods. We prospectively assessed patients admitted to a COVID-19 reference center in Mexico City between March $16^{\text {th }}$ and May $21^{\text {st }}$, and split them into development and validation cohorts. Patients were segregated into a group that required admission to ICU, and a group that never required ICU admission and was discharged from hospitalization. By logistic regression, we constructed predictive models for ICU admission, including clinical, laboratory, and imaging findings from the emergency department evaluation. The ABC-GOALS score was created by assigning values to the weighted odd ratios. The score was compared to other COVID-19 and pneumonia scores through the area under the curve (AUC).

Results. We included 569 patients divided into development $(n=329)$ and validation $(n=240)$ cohorts. One-hundred-fifteen patients from each cohort required admission to ICU. The clinical model (ABC-GOALS ) included sex, obesity, the Charlson comorbidity index, dyspnea, arterial pressure, and respiratory rate at triage evaluation. The clinical plus laboratory model (ABC-GOALS $\mathrm{cl}_{1}$ ) added serum albumin, glucose, lactate dehydrogenase, and $\mathrm{S} / \mathrm{F}$ ratio to the clinical model. The model that included imaging (ABC-GOALS $\mathrm{c}_{\mathrm{c} x}$ ) added the CT scan finding of $>50 \%$ lung involvement. The model AUC were $0.79(95 \% \mathrm{Cl} 0.74-0.83)$ and $0.77(95 \% \mathrm{Cl} 0.71$ $0.83), 0.86(95 \% \mathrm{Cl} 0.82-0.90)$ and $0.87(95 \% \mathrm{Cl} 0.83-0.92), 0.88(95 \% \mathrm{Cl} 0.84-0.92)$ and $0.86(95 \% \mathrm{Cl} 0.81-0.90)$ for the clinical, laboratory and imaging models in the development and validation cohorts, respectively. The ABC-GOALS $S_{c l}$ and ABC-

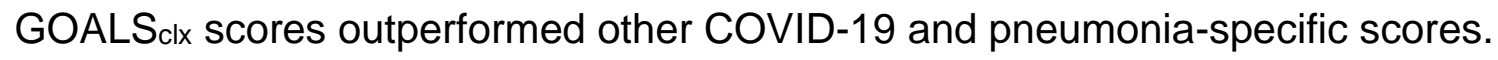

Conclusion. The ABC-GOALS score is a tool to evaluate patients with COVID-19 at admission to the emergency department, which allows to timely predict their risk of admission to an ICU. 


\section{INTRODUCTION}

The presence of a new severe acute respiratory syndrome coronavirus 2 (SARSCoV-2) was first reported in China and has subsequently spread to all regions of the world, straining the health systems of many countries ${ }^{1}$. Viral pneumonia associated with SARS-CoV-2 has been officially denominated as coronavirus disease 2019 (COVID-19)².

Approximately 5 to $33 \%$ of patients with COVID-19 pneumonia will be admitted to an intensive care unit (ICU) ${ }^{3-5}$. Previous studies have identified several risk factors associated with a severe course of COVID-19 pneumonia and its progression to acute respiratory distress syndrome ${ }^{6,7}$. These risk factors may be categorized into patient characteristics obtained through the medical interview (e.g. age, comorbidities, symptoms) ${ }^{6-11}$; vital signs obtained from triage evaluation (e.g. respiratory rate, arterial pressure) ${ }^{12,13}$; laboratory abnormalities including inflammatory, coagulation and organ-specific studies (e.g. lactate dehydrogenase, D-dimer, fibrinogen, cardiac troponins, liver function tests, among others) 6,7,9-11,14; and lung imaging findings (e.g. number of affected lobes, estimated pneumonia extension) ${ }^{15,16}$.

In several countries, including Mexico, hospital reconversion and temporary care centers have been implemented to cope with a large number of COVID-19 patients

17. However, many of these centers are prepared to care for patients with supplemental oxygen requirements in general wards, but just a few patients who require admission to an intensive care unit (ICU) and mechanical ventilation. 
medRxiv preprint doi: https://doi.org/10.1101/2020.05.12.20099416; this version posted May 30, 2020. The copyright holder for this preprint

The study aimed to derive and validate simple risk prediction models to anticipate the need for admission to an ICU. These models include clinical, laboratory, and image findings obtained at the first-contact evaluation to aid triage, decisionmaking, and timely referral to maintain healthcare system capacity.

\section{METHODS}

This is a prospective observational cohort study. All consecutive adult ( $>18$ years) patients hospitalized at Instituto Nacional de Ciencias Médicas y Nutrición Salvador Zubirán, a referral center for COVID-19 patients at Mexico City, were evaluated for this analysis. The study was approved by the local Research and Ethics Board (CAl-3368-20-20-1) that waived the use of a written informed consent form due to the study's nature.

All patients hospitalized between March $16^{\text {th }}$ and April $30^{\text {th }}$ were assigned to the development cohort, and patients hospitalized between May $1^{\text {st }}$ and May $21^{\text {th }}$ were assigned to the validation cohort. The study population was segregated into two groups: 1) patients who required admission to an ICU at any time during their hospitalization, and 2) patients admitted to hospital general wards who were discharged from hospitalization without ever been considered for admission to an ICU. Patients were censored for each group once they were admitted to the ICU or by the date of discharge from hospitalization to home, respectively. All patients who remained hospitalized in general wards by the end of the study were not 
included in this analysis as it was considered that their risk for ICU admission was still active.

All patients had COVID-19 pneumonia diagnosed by chest computed tomography (CT), and SARS-CoV-2 infection confirmed in respiratory specimens using realtime reverse-transcriptase polymerase chain reaction (RT-PCR) assay by local testing and confirmed at a central laboratory. Patients were considered positive if the initial test results were positive, or if it was negative but repeat testing was positive.

The following variables were obtained by the time of the triage and emergency department (ED) evaluation: demographic variables, previous medical and medication history including smoking; symptoms, physical examination including weight, height, and vital signs; laboratory evaluation including arterial blood gas analysis, inflammatory biomarkers, troponin-I levels, complete blood count and blood chemistries; and chest CT-scan findings. All patients underwent chest CTscans that were evaluated by experienced specialists; lung involvement was semiquantitatively classified as mild $(<20 \%)$, moderate $(20-50 \%)$, or severe $(>50 \%)$.

For each patient, we calculated the Charlson comorbidity index (an index that predicts 10-year survival in patients with multiple comorbidities) ${ }^{18}$, National Early Warning Score (NEWS) $2^{19}$, Sequential Organ Failure Assessment (SOFA) score ${ }^{20}$, CURB-65 score for pneumonia severity ${ }^{21}$, the MuLBSTA score for viral pneumonia mortality ${ }^{22}$, the ROX index to predict the risk of intubation ${ }^{23}$, the CALL score model for prediction of progression risk in COVID-19 ${ }^{24}$ and the COVIDGRAM score for the risk of critical illness in COVID-1925. All scores were calculated 
medRxiv preprint doi: https://doi.org/10.1101/2020.05.12.20099416; this version posted May 30, 2020. The copyright holder for this preprint

at admission to the ED. Although some of these scores were not derived to evaluate the risk of admission to an ICU, we evaluated their value if repurposed for this end.

The need for admission to critical care was determined by the medical team in charge of the patient and included the need for mechanical ventilation or high-dose vasopressors. Patients hospitalized in medical wards were treated with supplementary oxygen (nasal cannula or non-rebreathing oxygen mask) but were never considered for intubation and ICU admission. All patients in the latter group were censored once discharged from hospitalization to home after improvement. Clinical outcomes for patients admitted to ICU were monitored up to May $25^{\text {th, }}$ 2020.

\section{Statistical analysis}

The distribution of continuous variables was evaluated by the Kolmogorov-Smirnov test. Variables are described as number (relative frequency) or median (interquartile range $[\mathrm{IQR}]$ ) as appropriate. Characteristics at admission between study groups were compared by the Mann-Whitney $U$ test. There were less than $2 \%$ missing values for all variables. In the case of missing data, variables were imputed by using multiple imputations ${ }^{26}$.

For score derivation, all variables were evaluated by bivariate logistic regression analysis. All variables with $p$-values $<0.05$ were considered for the multivariate logistic regression analysis. The best logistic regression analysis model was 
constructed by the forward stepwise selection method using maximum likelihood estimation and r-square values. Three models were constructed: a first model including only clinical variables (ABC-GOALS $)$, a second model that included clinical and laboratory variables (ABC-GOALS $\left.{ }_{\mathrm{cl}}\right)$, and a third model that included clinical, laboratory, and x-ray findings (ABC-GOALS $\left.S_{c \mid x}\right)$. The predictive performance of each model was measured by the concordance index (C-index) and internal calibration was evaluated by 1000 bootstrap samples. The goodness of fit was evaluated by the Hosmer-Lemeshow test. To create the final scores, points were assigned by the weighted odd-ratios and approached to the closest integer for each model.

We prospectively validated the ABC-GOALS scores in an independent validation cohort. The performance of the derived scores as well as for all other scores determined at admission to predict the risk of hospitalization into an ICU were assessed by receiver operating characteristic (ROC) curves and their $95 \%$ confidence intervals.

All analyses were performed with SPSS version 24.0 (IBM, Armonk, NY, USA) and GraphPad Prism 6.0 (GraphPad Software, San Diego, CA, USA).

\section{RESULTS}

\section{Patient characteristics at admission}

A total of 705 patients with COVID-19 pneumonia and SARS-CoV-2 positive test were hospitalized during the study period. Eighty-three patients who remained 
hospitalized in general wards, 28 patients referred to a convalescence center, 22 early referred to other institutions, and three patients who were discharged by discharge against medical advice were excluded from the analysis. The development cohort included 329 patients and the validation cohort 240 patients (Figure 1).

\section{Characteristics of the development cohort}

The development cohort comprised 115 patients that required ICU admission and 214 patients that had been hospitalized and discharged from general wards. The median age of the derivation cohort was 49 years (IQR 41-60), 211 (64\%) subjects were male, with a median Charlson comorbidity index of 1 point (IQR 0-2). There were $100(30 \%)$ subjects with no previous comorbidity. The median days from the start of symptoms to the evaluation at the ER were 7 days (IQR 5-10). All patients received supplementary oxygen. For the group admitted to $\mathrm{ICU}$, the median time from ER admission to ICU admission was 2 days (IQR 0-3 days, range 0 to 12). The median length of hospitalization for the group hospitalized in general wards was 6 days (IQR 4-9 days, range 1 to 20). Several differences in the admission variables were observed between patients who required critical care and those hospitalized in general wards and are described in Table 1 and Supplementary Table 1. 
medRxiv preprint doi: https://doi.org/10.1101/2020.05.12.20099416; this version posted May 30, 2020. The copyright holder for this preprint

(which was not certified by peer review) is the author/funder, who has granted medRxiv a license to display the preprint in perpetuity.

It is made available under a CC-BY-NC-ND 4.0 International license .

\section{Factors associated with the need for admission to a critical care unit}

An extended table with all the results obtained from the bivariate logistic regression analysis is shown in Supplementary Table 2. The best predictive models derived from multivariable logistic regression analysis are shown in Table 2. The clinical model included: male sex, the Charlson comorbidity index, obesity $\left(B M I \geq 30 \mathrm{~kg} / \mathrm{m}^{2}\right.$, not included in the Charlson index), referred dyspnea, respiratory rate, and systolic arterial pressure at the triage or ER evaluation. The clinical plus laboratory model included the same clinical variables plus serum albumin $<3.5 \mathrm{~g} / \mathrm{dL}$, lactate dehydrogenase above the upper limit of normal, and the hemoglobin oxygen saturation to the fraction of inspired oxygen ratio $<300$ (S/F ratio). The clinical plus laboratory model included all previous variables except for referred dyspnea and serum albumin and added reported lung involvement $>50 \%$ in the lung CT scan. The c-statistics for clinical, clinical plus laboratory and clinical plus laboratory plus $\mathrm{x}$-ray models were $0.79,0.87$, and 0.88 , respectively.

\section{Derivation of the ABC-GOALS scores}

A predictive point score was constructed based on the weighted OR's from each logistic regression model. The derived scores were defined as the ABC-GOALS (Arterial pressure, Breathlessness, Charlson, Glucose, Obesity, Albumin, LDH and $\mathrm{S} / \mathrm{F}$ ratio) and were labeled as clinical $(\mathrm{ABC}-\mathrm{GOALS} \mathrm{C})$, clinical plus laboratory (ABC-GOALS $\left.\mathrm{C}_{\mathrm{c}}\right)$ and clinical plus laboratory plus x-ray $\left(\mathrm{ABC}-\mathrm{GOALS} \mathrm{S}_{\mathrm{cl}}\right)$ scores (Figure 2). 
All three ABC-GOALS score variations demonstrated good accuracy in estimating the risk of admission to an ICU, with an area under the curve of $0.79(95 \% \mathrm{CI} 0.74$ $0.83), 0.86(95 \% \mathrm{Cl} 0.82-0.90)$ and $0.88(95 \% \mathrm{Cl} 0.84-0.92)$ for the ABC-GOALS,

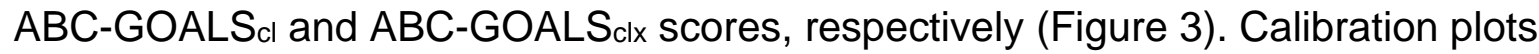
showed good agreement between the estimated and observed scores (Supplementary Figure 1).

By segregating the scores into three levels of risk of admission to ICU, the ABCGOALS $_{c}$ classified patients into low- (0-2 points, mean risk 8\%, 95\%Cl 7-9\%), moderate- (3-7 points, mean risk 32\%, 95\%Cl 30-34\%) and high-risk ( $\geq 8$ points, mean risk $73 \%, 95 \% \mathrm{Cl} 70-75 \%$ ) of admission ICU. The respective groups for the ABC-GOALS $\mathrm{cl}_{\mathrm{I}}$ were low- (0-3 points, mean risk 4\%, 95\%Cl 3-4\%), moderate- (4-9 points, mean risk $30 \%, 95 \% \mathrm{Cl} 27-32 \%$ ) and high-risk ( $\geq 10$ points, mean risk $80 \%$, $95 \% \mathrm{CI} 78-82 \%$ ) for ICU admission. Finally, the groups for the ABC-GOALS $\mathrm{clx}$ were low- (0-4 points, mean risk 6\%, 95\%Cl 5-6\%), moderate- (5-9 points, mean 32\%, 95\%Cl $29-34 \%$ ) and high-risk ( $\geq 10$ points, mean $80 \%, 95 \% \mathrm{Cl} 78-82 \%$ ) for ICU admission (Figure 2). The sensitivity and specificity for selected cutoffs of these scores are shown in Table 3.

The ABC-GOALS variants outperformed other scores that were repurposed for the prediction of admission to ICU, based on the area under the curve values (Table 3). As previously stated, most of these scores were not created to predict this outcome. For practicality, the three ABC-GOALS scores were implemented into an application for mobile devices. 


\section{Validation of the ABC-GOALS scores}

The ABC-GOALS scores were prospectively validated in consecutive patients included into the validation cohort. The characteristics of the patients included in this cohort are shown in Supplementary Table 3. The area under the curve for each score was $0.77(95 \% \mathrm{Cl} 0.71-0.83), 0.87(95 \% \mathrm{Cl} 0.83-0.91)$, and $0.86(95 \% \mathrm{Cl}$ 0.81-0.90) for the ABC-GOALS, ABC-GOALS $\mathrm{cl}$, and ABC-GOALS $\mathrm{clx}$, respectively (Figure 3). The ABC-GOALS scores' predictive performance was also superior to other scores in the validation cohort (Table 3).

\section{Outcomes}

By the end of this study (May 24 ${ }^{\text {th }}$ ), all patients hospitalized in general wards in the development and validation cohorts were discharged to home after improvement. Three patients $(0.8 \%)$ were readmitted and discharged again without admission to ICU during the study period. From all patients admitted to the ICU in the development cohort ( $n=115), 63(55 \%)$ have died, 37 (32\%) have been discharged to their homes after improvement, and $15(13 \%)$ remain hospitalized.

\section{DISCUSSION}

In this study, we derived and validated a prognostic score that, evaluated upon patient admission to the ED, helps predict the probability of admission to ICU 
during patient hospitalization. This tool may prove useful for patient assessment at first-contact evaluation and to timely refer patients to other units in case of a lack of or overcrowding of local ICUs. The ABC-GOALS scores predicted the need for admission to an ICU with greater accuracy than other reported COVID-19 prognostic scores, as well as other scores that were created for the prediction of other outcomes in sepsis or pneumonia, such as mortality.

To date, more than 4 million SARS-CoV-2 infections have been reported worldwide with more than 300,000 total deaths ${ }^{27}$. The fast spread of the disease ${ }^{28}$ and the large number of patients admitted to hospitals has strained and overwhelmed local health systems. Among hospitalized patients, 5 to $33 \%$ will require admission to an ICU and $75 \%$ to $100 \%$ of them will require support with mechanical ventilation ${ }^{3-5,8}$. An effective evaluation of patients with severe disease may be critical to maintain the healthcare system functional for as long as possible.

The ABC-GOALS scores summarize many of the previously reported factors that have been shown to independently associate with severe COVID-19 disease. We found that age and comorbidities predictive performance is enhanced when integrated into the Charlson comorbidity index. It has been reported in other studies that there may be interactions between age and some comorbidities such as diabetes ${ }^{29}$. Also, the Charlson comorbidity index offers the advantage of integrating several comorbidities into one score that has been previously associated with survival ${ }^{18}$. Among clinical symptoms, dyspnea or shortness of breath is the most consistently reported symptom associated with COVID-19 severity and mortality ${ }^{6,9,12,30}$ and was independently associated with ICU 
medRxiv preprint doi: https://doi.org/10.1101/2020.05.12.20099416; this version posted May 30, 2020. The copyright holder for this preprint

admission in this study. Obesity is a long-recognized factor for severe pulmonary infections ${ }^{31}$ and has been consistently associated with adverse outcomes in COVID-19 ${ }^{32}$. Low systolic arterial pressure and respiratory rate at triage evaluation complete the clinical ABC-GOALS.

Among the three derived scores in this study, the clinical ABC-GOALS has an inferior performance and probably equivalent to other early warning scores. It was designed to provide a tool for areas without timely access to laboratory results. However, the clinical score remains to be externally validated, as some reported models based exclusively on demographic (but not physical examination) information have been shown to decrease their performance after external validation $^{12}$.

The scores integrating clinical with laboratory $\left(A B C-G O A L S_{c 1}\right)$ and imaging (ABCGOALS ${ }_{c \mid x}$ ) findings seem to perform better for prediction of admission to an ICU. Both models include values of glucose, lactate dehydrogenase, and oxygenation at admission that have been previously reported to be associated with prognosis in COVID-19 9,11,33,34. Lactate dehydrogenase has been previously integrated into a predictive model (see below). In contrast to other laboratory tests that may increase during the progression of the disease, such as D-dimer and cardiac troponin levels ${ }^{35,36}, \mathrm{LDH}$ has proved to be the most robust laboratory predictor for admission to ICU when evaluated at first-contact. Glucose and oxygenation were also included in these models. Oxygenation, reflected by the S/F ratio, probably reflects the disease extension along with the imaging findings. It is worth noting that the model that included imaging findings $\left(A B C-G O A L S_{c \mid x}\right)$ had an equivalent 
performance to the clinical and laboratory model, therefore, it may not be necessary to perform imaging in a patient who is planned to be referred based on the clinical plus laboratory model (ABC-GOALS $\left.{ }_{\mathrm{cl}}\right)$.

We evaluated two scoring models that have been derived to predict the risk of COVID-19 progression: the CALL score ${ }^{24}$ and the COVID-GRAM score ${ }^{25}$. Both were derived from Chinese populations. As shown, both scores had lower performance than the ABC-GOALS scores in our population. The CALL score ${ }^{24}$ includes the presence of any comorbidity, age, lymphocyte count, and LDH levels. Most patients in our study presented with lymphocyte count below the cut-off set in the CALL score, therefore reducing the predictive value of the score and of this specific parameter. For the COVID-GRAM score ${ }^{25}$, it includes X-ray abnormalities, which were present in all of our patients by lung CT-scan. It also includes rare manifestations of COVID-19 that were barely documented in our population, such as hemoptysis and unconsciousness. Both, the CALL and COVID-GRAM scores, were derived from populations with a lower risk of critical care admission than our population, as $19.2 \%$ and $8.2 \%$ of the patients developed critical illness, respectively, compared to $34.9 \%$ and $47.9 \%$ in our development and validation cohorts, respectively. Thus, specific items included in the scores plus the derivation from a population with a lower risk for ICU admission may explain the lower performance of these scores in our population.

We showed that repurposing of other scores employed in pneumonia may not perform adequately to predict the need for admission to ICU in COVID-19 pneumonia. For example, the MuLBSTA score ${ }^{22}$ has been validated for mortality 
prediction in viral pneumonia but may have a lower performance in COVID-19 pneumonia. This score includes the number of affected lobes by viral pneumonia, however, all patients in our study showed multi-lobar lung infiltrates reducing the performance of this parameter. Other variables included in this score, such as bacterial coinfection, may not perform well when evaluated at admission, as bacterial coinfection more frequently occurs later in the disease evolution.

This study has some strengths. First, all data were collected prospectively with very few missing data for all collected variables. Second, there was an appropriate number of patients in the group that required admission to an ICU, which allowed the study of multiple predictors. Third, the study is reported based on TRIPOD guidelines ${ }^{37}$.

There are limitations to this study. The study included a single-center and very sick population with high rates of ICU admission; therefore, the score may perform well in severe hospitalized patients with COVID-pneumonia. There is still a need for external validation. Another limitation is that medical practice and admission criteria to ICU may vary between institutions and countries, especially in stressed health systems. This score was derived from a population living in Mexico City at $>7300$ feet over the sea level. The mean partial pressure of oxygen at this altitude has been estimated at around $66 \mathrm{mmHg}$ (estimated normal baseline $\mathrm{P} / \mathrm{F}$ ratio $\approx 314$ ) 38,39. Therefore, we used the S/F ratio to account for respiratory compensation and the right-shift of the hemoglobin dissociation curve that takes place at higher altitudes. Finally, the thresholds set to define the low-, moderate- and high-risk 
groups should be adapted to local needs and ICU availability. Therefore, we provided the estimated percentages of ICU admission for each sum of the score.

In summary, the ABC-GOALS score represents a tool to evaluate patients with COVID-19 at admission to the ED, designed to timely predict their risk of admission to an ICU. This score may help early referral and planning of attention during the COVID-19 pandemic.

\section{FUNDING}

None.

\section{DECLARATION OF INTEREST.}

None.

\section{ACKNOWLEDGEMENTS.}

The authors want to acknowledge all the health care team at Instituto Nacional de Ciencias Médicas y Nutrición Salvador Zubirán at Mexico City for their extraordinary work during this pandemic. We thank Pablo Galindo-Vallejo and Mauricio Moreno-Yañez for the development of the mobile phone application. 


\section{BIBLIOGRAPHY}

1. Emanuel EJ, Persad G, Upshur R, et al. Fair Allocation of Scarce Medical

Resources in the Time of Covid-19. N Engl J Med 2020; 382:2049-2055

2. World Health Organization. Naming the coronavirus disease (COVID-19) and the virus that causes it. Available from:

www.who.int/emergencies/diseases/novel-coronavirus-2019/technicalguidance/naming-the-coronavirus-disease-(covid-2019)-and-the-virus-that-causesit. Accessed 20May2020.

3. Wu Z, McGoogan JM. Characteristics of and Important Lessons From the Coronavirus Disease 2019 (COVID-19) Outbreak in China. JAMA 2020; doi:10.1001/jama.2020.2648

4. Goyal P, Choi JJ, Pinheiro LC, et al. Clinical Characteristics of Covid-19 in New York City. N Engl J Med 2020; doi:10.1056/NEJMc2010419

5. Richardson S, Hirsch JS, Narasimhan M, et al. Presenting Characteristics, Comorbidities, and Outcomes Among 5700 Patients Hospitalized With COVID-19 in the New York City Area. JAMA 2020; doi:10.1001/jama.2020.6775

6. Wu C, Chen X, Cai Y, et al. Risk Factors Associated With Acute Respiratory Distress Syndrome and Death in Patients With Coronavirus Disease 2019

Pneumonia in Wuhan, China. JAMA Intern Med 2020; doi:

10.1001/jamainternmed.2020.0994 
7. Hu L, Chen S, Fu Y, et al. Risk Factors Associated with Clinical Outcomes in 323 COVID-19 Hospitalized Patients in Wuhan, China. Clin Infect Dis 2020; doi: $10.1093 /$ cid/ciaa539

8. Guan W, Ni Z, Hu Y, et al. Clinical Characteristics of Coronavirus Disease 2019 in China. N Engl J Med 2020; 382: 1708-1720

9. Chen R, Liang W, Jiang M, et al. Risk Factors of Fatal Outcome in Hospitalized Subjects With Coronavirus Disease 2019 From a Nationwide Analysis in China. Chest 2020; doi: 10.1016/j.chest.2020.04.010

10. Chen N, Zhou M, Dong X, et al. Epidemiological and clinical characteristics of 99 cases of 2019 novel coronavirus pneumonia in Wuhan, China: a descriptive study. Lancet 2020; 395: 507-513

11. Deng G, Yin M, Chen X, Zeng F. Clinical determinants for fatality of 44,672 patients with COVID-19. Crit Care 2020; 24: 179

12. Zhang $\mathrm{H}$, Shi $\mathrm{T}$, Wu X, et al. Risk prediction for poor outcome and death in hospital in patients with COVID-19: derivation in Wuhan, China and external validation in London, UK. medRxiv [preprint]. Available from:

https://doi.org/10.1101/2020.04.28.20082222

13. Wang K, Zuo P, Liu Y, et al. Clinical and Laboratory Predictors of In-Hospital Mortality in Patients with COVID-19: A Cohort Study in Wuhan, China. Clin Infect Dis 2020; doi:10.1093/cid/ciaa538 
14. Yang R, Gui X, Zhang $Y$, Xiong $Y$. The role of essential organ-based comorbidities in the prognosis of COVID-19 infection patients. Expert Rev Respir Med 2020;1-4

15. Zhang J, Yu M, Tong S, Liu LY, Tang LV. Predictive factors for disease progression in hospitalized patients with coronavirus disease 2019 in Wuhan, China. J Clin Virol 2020; 127:104392

16. Chu Y, Li T, Fang Q, Wang X. Clinical characteristics and imaging manifestations of the 2019 novel coronavirus disease (COVID-19): A multi-center study in Wenzhou city, Zhejiang, China. J Infect 2020; 388-393

17. Grasselli G, Pesenti A, Cecconi M. Critical Care Utilization for the COVID-19 Outbreak in Lombardy, Italy. JAMA 2020; 323: 1545

18. Charlson ME, Pompei P, Ales KL, MacKenzie CR. A new method of classifying prognostic comorbidity in longitudinal studies: Development and validation. J Chronic Dis 1987; 40: 373-383

19. Royal College of Physicians. National Early Warning Score (NEWS) 2:

Standardising the Assessment of Acute-IIIness Severity in the NHS; RCP Press: London, UK, 2017.

20. Vincent JL, Moreno R, Takala J, et al. The SOFA (Sepsis-related Organ Failure Assessment) score to describe organ dysfunction/failure. Intensive Care Med 1996; 22: 707-710 
medRxiv preprint doi: https://doi.org/10.1101/2020.05.12.20099416; this version posted May 30, 2020. The copyright holder for this preprint

21. Lim WS. Defining community acquired pneumonia severity on presentation to hospital: an international derivation and validation study. Thorax 2003; 58: 377382

22. Guo L, Wei D, Zhang X, et al. Clinical Features Predicting Mortality Risk in Patients with Viral Pneumonia: The MuLBSTA Score. Front Microbiol 2019; $10: 2752$

23. Roca O, Messika J, Caralt B, et al. Predicting success of high-flow nasal cannula in pneumonia patients with hypoxemic respiratory failure: The utility of the ROX index. J Crit Care 2016; 35: 200-205

24. Ji D, Zhang D, Xu J, et al. Prediction for Progression Risk in Patients with COVID-19 Pneumonia: the CALL Score. Clin Infect Dis 2020; doi:

\subsection{3/cid/ciaa414}

25. Liang W, Liang $\mathrm{H}, \mathrm{Ou} \mathrm{L}$, et al. Development and validation of a clinical risk score to predict the occurrence of critical illness in hospitalized patients with COVID-19. JAMA Int Med 2020; doi: 10.1001/jamainternmed.2020.2033

26. Sterne JAC, White IR, Carlin JB, et al. Multiple imputation for missing data in epidemiological and clinical research: potential and pitfalls. BMJ 2009; 338: b2393-b2393. 26. Johns Hopkins University coronavirus resource center. Available from: https://coronavirus.jhu.edu/map.html. Accessed 20May2020

27. Li Q, Guan X, Wu P, et al. Early Transmission Dynamics in Wuhan, China, of Novel Coronavirus-Infected Pneumonia. N Engl J Med 2020; 382:1199-1207 
28. Bello-Chavolla OY, Bahena-López JP, Antonio-Villa NE, et al. Predicting mortality due to SARS-CoV-2: a mechanistic score relating obesity and diabetes to COVID-19 outcomes in Mexico. medRxiv [preprint]. Available from: https://doi.org/10.1101/2020.04.20.20072223

29. Bhatraju PK, Ghassemieh BJ, Nichols M, et al. Covid-19 in Critically III Patients in the Seattle Region - Case Series. N Engl J Med 2020; 382: 2012-2022

30. Luzi L, Radaelli MG. Influenza and obesity: its odd relationship and the lessons for COVID-19 pandemic. Acta Diabetol 2020; 57: 759-764

31. Dietz W, Santos-Burgoa C. Obesity and its Implications for COVID-19 Mortality. Obesity 2020; doi: 10.1002/oby.22818

32. Levy TJ, Richardson S, Coppa K, et al. Estimating survival of hospitalized COVID-19 patients from admission information. medRxiv [preprint]. Available from: http://medrxiv.org/content/10.1101/2020.04.22.20075416v2.

33. Mo P, Xing Y, Xiao Y, et al. Clinical characteristics of refractory COVID-19 pneumonia in Wuhan, China. Clin Infect Dis 2020; doi: 10.1093/cid/ciaa270

34. Guo T, Fan Y, Chen M, et al. Cardiovascular Implications of Fatal Outcomes of Patients With Coronavirus Disease 2019 (COVID-19). JAMA Cardiol 2020; doi: 10.1001/jamacardio.2020.1017

35. Wang D, Yin Y, Hu C, et al. Clinical course and outcome of 107 patients infected with the novel coronavirus, SARS-CoV-2, discharged from two hospitals in Wuhan, China. Crit Care 2020; 24: 188 
36. Collins GS, Reitsma JB, Altman DG, Moons KGM. Transparent reporting of a multivariable prediction model for individual prognosis or diagnosis (TRIPOD): the TRIPOD statement. BMJ 2015; 350: g7594-g7594

37. Pérez-Padilla JR, Vázquez-García JC. Estimation of gasometric values at different altitudes above sea level in Mexico. Rev Invest Clin 2000; 52: 148-155

38. Ramirez-Sandoval JC, Castilla-Peón MF, Gotés-Palazuelos J, et al.

Bicarbonate Values for Healthy Residents Living in Cities Above 1500 Meters of Altitude: A Theoretical Model and Systematic Review. High Alt Med Biol 2016; 17: 85-92 
medRxiv preprint doi: https://doi.org/10.1101/2020.05.12.20099416; this version posted May 30, 2020. The copyright holder for this preprint (which was not certified by peer review) is the author/funder, who has granted medRxiv a license to display the preprint in perpetuity.

It is made available under a CC-BY-NC-ND 4.0 International license .

\section{TABLES}

Table 1. Characteristics of patients in the development cohort at first evaluation in the emergency department.

\begin{tabular}{|c|c|c|c|c|}
\hline & $\begin{array}{c}\text { All patients } \\
n=329\end{array}$ & $\begin{array}{c}\text { Critical Care } \\
n=115\end{array}$ & $\begin{array}{c}\text { General wards } \\
n=214\end{array}$ & p-value \\
\hline Age, years & $49(41-60)$ & $53(43-62)$ & $49(39-59)$ & 0.009 \\
\hline Male gender, $n(\%)$ & $211(64)$ & $88(77)$ & $123(58)$ & $<0.001$ \\
\hline Current/past smoker, n (\%) & $23(7)$ & $10(9)$ & $13(6)$ & 0.497 \\
\hline \multicolumn{5}{|l|}{ Comorbidities } \\
\hline Diabetes mellitus, $\mathrm{n}(\%)$ & $80(24)$ & $37(32)$ & $43(20)$ & 0.016 \\
\hline Hypertension, n (\%) & $88(27)$ & $33(29)$ & $55(26)$ & 0.602 \\
\hline Obesity, n (\%) & $132(40)$ & $59(51)$ & $73(34)$ & 0.003 \\
\hline CKD, n (\%) & $19(6)$ & $7(6)$ & $12(6)$ & 0.807 \\
\hline None, n (\%) & $100(30)$ & $18(16)$ & $82(38)$ & $<0.001$ \\
\hline Charlson index, points & $1(0-2)$ & $1(0-3)$ & $1(0-2)$ & 0.001 \\
\hline 0 points & $141(43)$ & $36(31)$ & $105(49)$ & 0.002 \\
\hline $1-2$ points & $125(38)$ & $47(41)$ & $78(36)$ & \\
\hline$\geq 3$ points & $63(19)$ & $32(28)$ & $31(15)$ & \\
\hline \multicolumn{5}{|l|}{ Clinical Presentation } \\
\hline Fever, n (\%) & 302 (92) & $104(90)$ & $198(93)$ & 0.532 \\
\hline Cough, n (\%) & $285(87)$ & $103(90)$ & $182(85)$ & 0.309 \\
\hline Myalgia / arthralgia, $n(\%)$ & $148(45)$ & $40(35)$ & $108(51)$ & 0.007 \\
\hline Sore throat, n (\%) & $100(30)$ & $36(31)$ & $64(30)$ & 0.803 \\
\hline Rhinorrhea, n (\%) & $51(16)$ & $19(17)$ & $32(15)$ & 0.750 \\
\hline Headache, $\mathrm{n}(\%)$ & $162(49)$ & $56(49)$ & $106(50)$ & 0.908 \\
\hline Dyspnea, n (\%) & $229(70)$ & $98(85)$ & $131(61)$ & $<0.001$ \\
\hline Diarrhea, n (\%) & $56(17)$ & $21(18)$ & $35(16)$ & 0.759 \\
\hline Anosmia, n (\%) & $17(5)$ & $4(4)$ & $13(6)$ & 0.435 \\
\hline Days with symptoms & $7(5-10)$ & $7(5-9)$ & $8(5-10)$ & 0.595 \\
\hline \multicolumn{5}{|l|}{ Physical examination } \\
\hline Body mass index, $\mathrm{kg} / \mathrm{m}^{2}$ & $29.0(26.5-31.2)$ & $29.6(26.9-33.4)$ & $28.9(26.3-30.6)$ & 0.006 \\
\hline Systolic AP<100 mmHg & $16(5)$ & $11(10)$ & $5(2)$ & 0.001 \\
\hline Respiratory rate, per min & $24(21-30)$ & $28(24-36)$ & $24(20-28)$ & $<0.001$ \\
\hline \multicolumn{5}{|l|}{ Laboratory evaluation } \\
\hline Total leukocytes, $\times 10^{3 / \mu \mathrm{L}}$ & $7.1(5.3-9.5)$ & $9.0(5.8-12.1)$ & $6.7(5.1-8.7)$ & $<0.001$ \\
\hline Neutrophils, $\times 10^{3} / \mu \mathrm{L}$ & $5.9(2.8-8.2)$ & $7.7(4.8-10.7)$ & $5.2(3.6-7.1)$ & $<0.001$ \\
\hline Lymphocytes, $x 10^{3} / \mu \mathrm{L}$ & $0.8(0.6-1.1)$ & $0.7(0.5-1.0)$ & $0.9(0.7-1.1)$ & $<0.001$ \\
\hline Hemoglobin, $\mathrm{g} / \mathrm{dL}$ & $15.5(14.4-16.6)$ & $15.5(14.4-16.5)$ & $15.6(14.2-16.6)$ & 0.843 \\
\hline Platelets, $\times 10^{3}$ & $208(165-257)$ & $215(166-266)$ & $206(165-256)$ & 0.515 \\
\hline Total bilirubin, mg/dL & $0.55(0.43-0.75)$ & $0.62(0.46-0.84)$ & $0.53(0.43-0.69)$ & 0.005 \\
\hline Direct bilirubin, mg/dL & $0.16(0.11-0.22)$ & $0.18(0.14-0.27)$ & $0.14(0.11-0.21)$ & $<0.001$ \\
\hline $\mathrm{ALT}, \mathrm{U} / \mathrm{L}$ & $34.3(23.3-52.7)$ & $37.3(23.9-52.7)$ & $33.7(22.3-52.6)$ & 0.574 \\
\hline AST, U/L & $39.3(27.9-57.6)$ & $46.6(33.3-67.8)$ & 36.5 (26.5-51.2) & $<0.001$ \\
\hline Alkaline phosphatase, $\mathrm{mg} / \mathrm{dL}$ & $83(68-105)$ & $84(70-107)$ & $83(67-103)$ & 0.608 \\
\hline Serum albumin, g/dL & $3.8(3.4-4.1)$ & $3.5(3.2-3.9)$ & $3.9(2.6-4.1)$ & $<0.001$ \\
\hline Serum globulins, g/dL & $3.2(3.0-3.5)$ & $3.3(3.0-3.6)$ & $3.2(2.9-3.5)$ & 0.608 \\
\hline Glucose, mg/dL & $115(100-147)$ & $138(111-213)$ & $107(97-128)$ & $<0.001$ \\
\hline $\mathrm{BUN}, \mathrm{mg} / \mathrm{dL}$ & $14.0(10.5-19.8)$ & $16.6(12.8-24.0)$ & $12.7(9.7-17.9)$ & $<0.001$ \\
\hline Creatinine, $\mathrm{mg} / \mathrm{dL}$ & $0.93(0.75-1.15)$ & $1.00(0.85-1.24)$ & $0.89(0.72-1.10)$ & $<0.001$ \\
\hline
\end{tabular}


medRxiv preprint doi: https://doi.org/10.1101/2020.05.12.20099416; this version posted May 30, 2020. The copyright holder for this preprint (which was not certified by peer review) is the author/funder, who has granted medRxiv a license to display the preprint in perpetuity.

It is made available under a CC-BY-NC-ND 4.0 International license .

Sodium, $\mathrm{mEq} / \mathrm{L}$

Potassium, $\mathrm{mEq} / \mathrm{L}$

Chloride, $\mathrm{mEq} / \mathrm{L}$

Total serum $\mathrm{CO}_{2}, \mathrm{mmol} / \mathrm{L}$

Creatine kinase, $\mathrm{U} / \mathrm{L}$

Lactate dehydrogenase, U/L

$C$ reactive protein, $\mathrm{mg} / \mathrm{dL}$

Ferritin, $\mathrm{ng} / \mathrm{mL}$

Troponin I >ULN (20pg/mL) n(\%)

Fibrinogen, mg/dL

D-dimer, $\mathrm{ng} / \mathrm{mL}$

$\begin{array}{cc}135(132-137) & 134(132-138) \\ 4.0(3.7-4.3) & 4.0(3.6-4.3) \\ 101(98-104) & 100(97-104) \\ 23.2(21.5-25.0) & 22.6(20.8-24.4) \\ 103(61-222) & 142(72-276) \\ 336(259-456) & 474(344-578) \\ 12.6(5.4-19.3) & 18.3(12.6-25.7) \\ 506(254-939) & 740(423-1092) \\ 35(10.6) & 28(24.3) \\ 604(457-723) & 688(542-807) \\ 628(398-1072) & 761(495-1323)\end{array}$

$135(132-137)$
7.44 (7.42-7.47)

$21.5(19.9-22.9)$

$1.2(0.9-1.6)$

$247(175-291)$

$330(211-426)$
7.44 (7.39-7.46)

$21.0(18.6-23.5)$

$1.5(1.0-2.1)$

$177(107-247)$

$193(149-325)$

$\begin{array}{cc}135(133-137) & 0.200 \\ 4.0(3.7-4.3) & 0.823 \\ 102(99-104) & 0.042 \\ 23.4(21.9-25.2) & 0.001 \\ 88(57-166) & 0.003 \\ 288(230-380) & <0.001 \\ 7.8(3.4-15.6) & <0.001 \\ 375(207-784) & <0.001 \\ 7(3.3) & <0.001 \\ 499(434-678) & <0.001 \\ 523(358-958) & <0.001\end{array}$

$7.45(7.42-7.47)$

$<0.001$

$21.6(20.5-22.8) \quad 0.122$

$1.1(0.9-1.4) \quad<0.001$

$269(229-305) \quad<0.001$

$410(315-433) \quad<0.001$

\section{Chest CT scan}

Multi-lobar

$329(100)$

$115(100)$

$214(100)$

1.000

Extension

$\begin{array}{lcccc}\text { Mild }(\leq 20 \%) & 57(17) & 3(3) & 54(25) & <0.001 \\ \text { Moderate }(21-50 \%) & 141(43) & 26(22) & 115(54) & \\ \text { Severe }(>50 \%) & 131(40) & 86(75) & 45(21) & \end{array}$

${ }^{*}$ Continuous variables are expressed as median (interquartile range).

Abbreviations. CKD, chronic kidney disease; AP, arterial pressure; ALT, alanine transaminase; AST, aspartate transaminase; $\mathrm{BUN}$, blood urea nitrogen; $\mathrm{CO}_{2}$, total diluted carbon dioxide; $\mathrm{PaO}_{2} / \mathrm{FiO}_{2}$ ratio, ratio of arterial pressure of oxygen to fraction of inspired oxygen; $\mathrm{SaFiO}_{2} / \mathrm{FiO}_{2}$, ratio of the percentage of hemoglobin saturation by oxygen to fraction of inspired oxygen; NEWS-2, National Early Warning Score 2; SOFA - $\mathrm{PaO}_{2} / \mathrm{FiO}_{2}$, Sequential Organ Failure Assessment score with respiratory points obtained by $\mathrm{PaO}_{2} / \mathrm{FiO}_{2}$ ratio; SOFA-SaO$/ \mathrm{FiO}_{2}$, Sequential Organ Failure Assessment score with respiratory points obtained by $\mathrm{SaO}_{2} / \mathrm{FiO}_{2}$. 
medRxiv preprint doi: https://doi.org/10.1101/2020.05.12.20099416; this version posted May 30, 2020. The copyright holder for this preprint (which was not certified by peer review) is the author/funder, who has granted medRxiv a license to display the preprint in perpetuity.

It is made available under a CC-BY-NC-ND 4.0 International license .

Table 2. Models to predict the risk of admission to an intensive care unit

\begin{tabular}{|c|c|c|c|c|c|c|}
\hline & OR & $\begin{array}{l}\text { Bivariate } \\
95 \% \mathrm{Cl}\end{array}$ & p-value & OR & $\begin{array}{l}\text { Multivariate } \\
95 \% \mathrm{Cl}\end{array}$ & $p$-value \\
\hline \multicolumn{7}{|l|}{ Model 1: clinical } \\
\hline Male gender & 2.41 & $1.45-4.01$ & 0.001 & 1.82 & $1.01-3.30$ & 0.049 \\
\hline Obesity, BMI $\geq 30 \mathrm{~kg} / \mathrm{m}^{2}$ & 2.04 & $1.28-3.23$ & 0.003 & 2.56 & $1.56-4.55$ & 0.001 \\
\hline Dyspnea & 3.65 & $2.04-6.55$ & $<0.001$ & 2.39 & $1.22-4.67$ & 0.022 \\
\hline $\mathrm{SBP}<100 \mathrm{mmHg}$ & 4.42 & $1.50-13.06$ & 0.007 & 5.10 & $1.37-18.9$ & 0.015 \\
\hline \multicolumn{7}{|l|}{ Respiratory rate } \\
\hline$<24$ per min & 1.00 & reference & reference & 1.00 & reference & reference \\
\hline $24-28$ per min & 2.253 & $1.223-4.150$ & 0.009 & 2.12 & $1.08-4.17$ & 0.029 \\
\hline$>28$ per min & 8.063 & $4.279-15.19$ & $<0.001$ & 5.14 & $2.50-10.7$ & $<0.001$ \\
\hline \multicolumn{7}{|l|}{ Charlson index } \\
\hline 0 points & 1.00 & reference & reference & 1.00 & reference & reference \\
\hline 1-2 points & 1.76 & $1.04-2.97$ & 0.035 & 2.33 & $1.28-4.27$ & 0.006 \\
\hline$\geq 3$ points & 3.01 & $1.62-5.61$ & 0.001 & 4.96 & $2.32-10.6$ & $<0.001$ \\
\hline \multicolumn{7}{|c|}{ Model 2: clinical + laboratory } \\
\hline Male gender & 2.41 & $1.45-4.01$ & 0.001 & 2.48 & $1.28-4.81$ & 0.007 \\
\hline Obesity, BMl>30kg/m² & 2.04 & $1.28-3.23$ & 0.003 & 2.97 & $1.59-5.55$ & 0.001 \\
\hline Dyspnea & 3.65 & $2.04-6.55$ & $<0.001$ & 2.24 & $1.08-4.61$ & 0.029 \\
\hline Charlson index $\geq 3$ & 2.28 & $1.30-3.98$ & 0.004 & 2.84 & $1.31-6.15$ & 0.008 \\
\hline $\mathrm{SBP}<100 \mathrm{mmHg}$ & 4.42 & $1.50-13.06$ & 0.007 & 5.71 & $1.31-24.9$ & 0.020 \\
\hline Glucose $>200 \mathrm{~g} / \mathrm{dL}$ & 3.10 & $1.67-5.74$ & $<0.001$ & 3.00 & $1.35-6.67$ & 0.007 \\
\hline Albumin $<3.5 \mathrm{~g} / \mathrm{dL}$ & 4.15 & $2.52-6.83$ & $<0.001$ & 2.13 & $1.14-3.99$ & 0.018 \\
\hline LDH $>$ ULN & 8.55 & $4.11-17.79$ & $<0.001$ & 3.39 & $1.47-7.79$ & 0.004 \\
\hline $\mathrm{S} / \mathrm{F}$ ratio $<300$ & 8.48 & $5.07-14.19$ & $<0.001$ & 5.41 & $2.93-9.97$ & $<0.001$ \\
\hline \multicolumn{7}{|c|}{ Model 3: clinical + laboratory + image } \\
\hline Male gender & 2.41 & $1.45-4.01$ & 0.001 & 2.14 & $1.09-4.18$ & 0.026 \\
\hline Obesity, BMl>30kg/m² & 2.04 & $1.28-3.23$ & 0.003 & 2.58 & $1.37-4.85$ & 0.003 \\
\hline Charlson index $\geq 3$ & 2.28 & $1.30-3.98$ & 0.004 & 2.90 & $1.32-6.37$ & 0.008 \\
\hline $\mathrm{SBP}<100 \mathrm{mmHg}$ & 4.42 & $1.50-13.06$ & 0.007 & 5.15 & $1.12-23.6$ & 0.035 \\
\hline Glucose $>200 \mathrm{mg} / \mathrm{dL}$ & 3.10 & $1.67-5.74$ & $<0.001$ & 2.64 & $1.14-6.12$ & 0.023 \\
\hline LDH>ULN & 8.55 & $4.11-17.79$ & $<0.001$ & 2.83 & $1.20-6.66$ & 0.017 \\
\hline $\mathrm{S} / \mathrm{F}$ ratio $<300$ & 8.48 & $5.07-14.19$ & $<0.001$ & 4.43 & $2.35-8.35$ & $<0.001$ \\
\hline CT lung involvement $>50 \%$ & 11.1 & $6.53-18.99$ & $<0.001$ & 4.62 & $2.47-8.64$ & $<0.001$ \\
\hline
\end{tabular}

Abbreviations. OR, odds ratio; 95\%Cl, 95\% confidence intervals; SBP, systolic blood pressure; LDH, lactate dehydrogenase serum levels; S/F ratio, ratio of percentage of hemoglobin saturation to fraction of inspired oxygen; CT, computed tomography. 
medRxiv preprint doi: https://doi.org/10.1101/2020.05.12.20099416; this version posted May 30, 2020. The copyright holder for this preprint (which was not certified by peer review) is the author/funder, who has granted medRxiv a license to display the preprint in perpetuity.

It is made available under a CC-BY-NC-ND 4.0 International license .

Table 3. Predictive performance for admission to ICU of all the evaluated scores.

\begin{tabular}{|c|c|c|}
\hline \multirow[b]{2}{*}{ Score } & \multicolumn{2}{|c|}{ Area under the curve } \\
\hline & $\begin{array}{c}\text { Development } \\
\text { cohort }\end{array}$ & $\begin{array}{c}\text { Validation } \\
\text { cohort }\end{array}$ \\
\hline$A B C-G O A L S_{c}$ & $\begin{array}{c}0.79 \\
(0.74-0.83)\end{array}$ & $\begin{array}{c}0.77 \\
(0.71-0.83)\end{array}$ \\
\hline$A B C-G O A L S_{c l}$ & $\begin{array}{c}0.86 \\
(0.82-0.90)\end{array}$ & $\begin{array}{c}0.87 \\
(0.83-0.92)\end{array}$ \\
\hline$A B C-G O A L S_{c \mid x}$ & $\begin{array}{c}0.88 \\
(0.84-0.92)\end{array}$ & $\begin{array}{c}0.86 \\
(0.81-0.90)\end{array}$ \\
\hline COVID-GRAM & $\begin{array}{c}0.78 \\
(0.73-0.83)\end{array}$ & $\begin{array}{c}0.77 \\
(0.72-0.83)\end{array}$ \\
\hline CALL score & $\begin{array}{c}0.72 \\
(0.67-0.78)\end{array}$ & $\begin{array}{c}0.69 \\
(0.63-0.76)\end{array}$ \\
\hline SOFA & $\begin{array}{c}0.77 \\
(0.71-0.82)\end{array}$ & $\begin{array}{c}0.73 \\
(0.66-0.79)\end{array}$ \\
\hline NEWS-2 & $\begin{array}{c}0.76 \\
(0.70-0.81)\end{array}$ & $\begin{array}{c}0.64 \\
(0.57-0.71)\end{array}$ \\
\hline CURB-65 & $\begin{array}{c}0.71 \\
(0.65-0.77)\end{array}$ & $\begin{array}{c}0.74 \\
(0.67-0.80)\end{array}$ \\
\hline MuLBSTA & $\begin{array}{c}0.63 \\
(0.57-0.70)\end{array}$ & $\begin{array}{c}0.58 \\
(0.50-0.0 .65)\end{array}$ \\
\hline ROX index & $\begin{array}{c}0.81 \\
(0.76-0.86)\end{array}$ & $\begin{array}{c}0.84 \\
(0.80-0.90)\end{array}$ \\
\hline
\end{tabular}

* All scores were obtained at admission to the emergency room. SOFA respiratory points were assigned based on the S/F ratio.

Abbreviations. ABC-GOALSc, score including only clinical variables; ABC-GOALScl, score including both clinical and laboratory variables; ABC-GOALSclx, score including clinical, laboratory and x-ray findings; NEWS-2, National Early Warning Score version 2; CALL, comorbidity, age, lymphocyte, LDH score for predicting progression of COVID-19; SOFA, Sequential Organ Failure Assessment score; CURB-65, confusion, urea, respiratory rate, blood pressure, age $>65$ years score for risk of mortality from pneumonia; MuLBSTA, Multi-lobar infiltrate, Lymphocyte count, Bacterial co-infection, Smoking history, hypertension, Age $>65$ years score for mortality from viral pneumonia; ROX index, $\mathrm{S} / \mathrm{F}$ ratio divided by the respiratory rate to predict the risk of intubation in hypoxemic respiratory failure. 
medRxiv preprint doi: https://doi.org/10.1101/2020.05.12.20099416; this version posted May 30, 2020. The copyright holder for this preprint (which was not certified by peer review) is the author/funder, who has granted medRxiv a license to display the preprint in perpetuity.

It is made available under a CC-BY-NC-ND 4.0 International license .

\section{FIGURES}

Figure 1. Flow diagram showing all subjects included in the study.

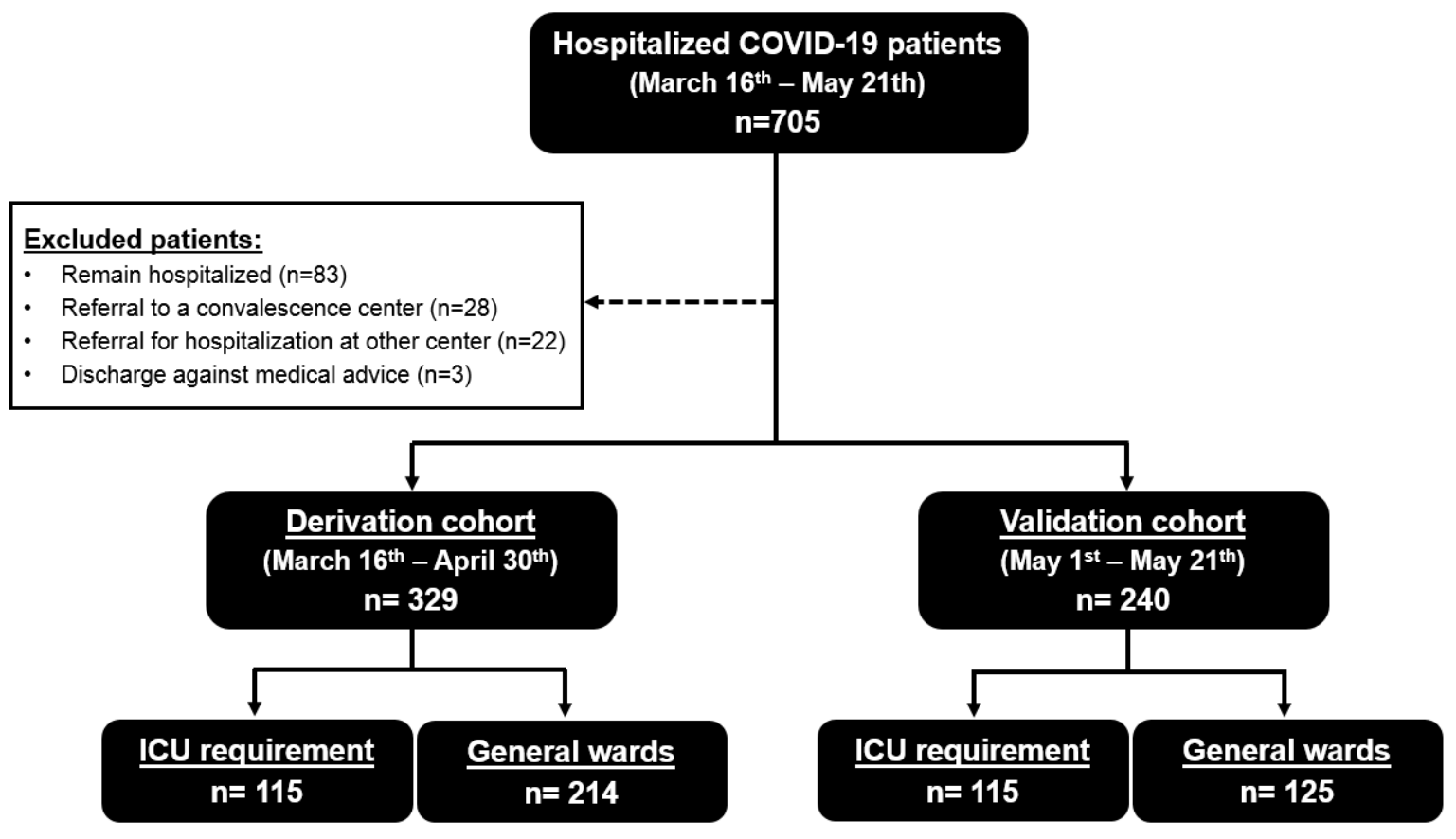


medRxiv preprint doi: https://doi.org/10.1101/2020.05.12.20099416; this version posted May 30, 2020. The copyright holder for this preprint (which was not certified by peer review) is the author/funder, who has granted medRxiv a license to display the preprint in perpetuity.

It is made available under a CC-BY-NC-ND 4.0 International license .

Figure 2. Guide to ABC-GOALS score calculation.

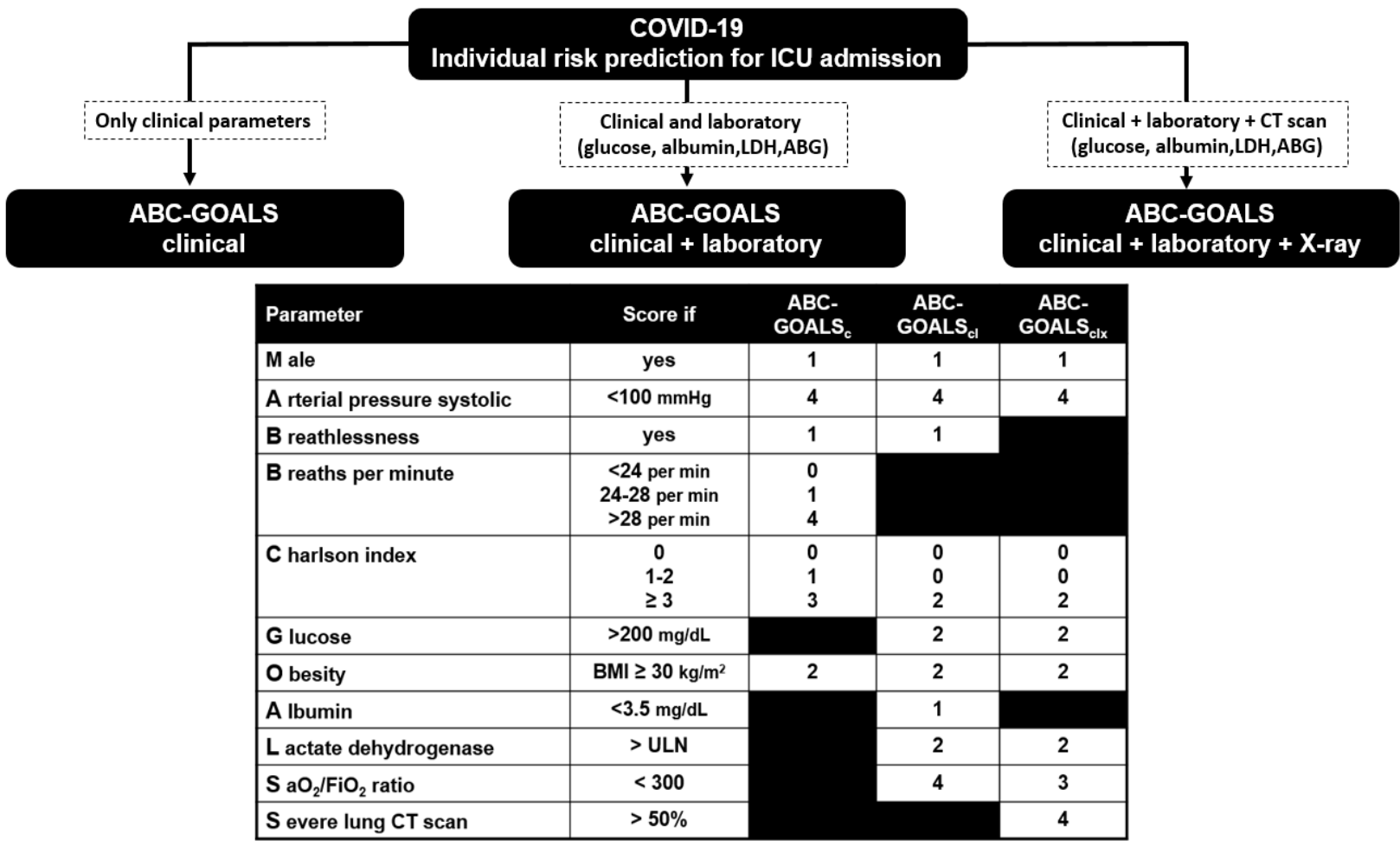

\begin{tabular}{|c|c|c|}
\hline \multicolumn{3}{|c|}{ ABC-GOALS clinic } \\
\hline Risk & Total Points & $\begin{array}{l}\text { Probability of } \\
\text { ICU } \\
\text { admission }\end{array}$ \\
\hline \multirow{3}{*}{ కై } & 0 & $3 \%$ \\
\hline & 1 & $5 \%$ \\
\hline & 2 & $11 \%$ \\
\hline \multirow{5}{*}{ 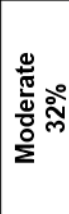 } & 3 & $18 \%$ \\
\hline & 4 & $27 \%$ \\
\hline & 5 & $37 \%$ \\
\hline & 6 & $46 \%$ \\
\hline & 7 & $53 \%$ \\
\hline \multirow{8}{*}{ 홍 } & 8 & $63 \%$ \\
\hline & 9 & $76 \%$ \\
\hline & 10 & $80 \%$ \\
\hline & 11 & $88 \%$ \\
\hline & 12 & $90 \%$ \\
\hline & 13 & $94 \%$ \\
\hline & 14 & $95 \%$ \\
\hline & 15 & $97 \%$ \\
\hline
\end{tabular}

\begin{tabular}{|c|c|c|}
\hline \multicolumn{3}{|c|}{ ABC-GOALS clinic + laboratory } \\
\hline Risk & Total Points & $\begin{array}{l}\text { Probability } \\
\text { of ICU } \\
\text { admission }\end{array}$ \\
\hline \multirow{4}{*}{ 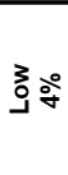 } & 0 & $4 \%$ \\
\hline & 1 & $10 \%$ \\
\hline & 2 & $13 \%$ \\
\hline & 3 & $13 \%$ \\
\hline \multirow{6}{*}{ 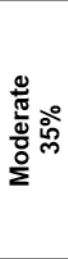 } & 4 & $23 \%$ \\
\hline & 5 & $33 \%$ \\
\hline & 6 & $35 \%$ \\
\hline & 7 & $35 \%$ \\
\hline & 8 & $36 \%$ \\
\hline & 9 & $40 \%$ \\
\hline \multirow{8}{*}{ 홍 } & 10 & $53 \%$ \\
\hline & 11 & $64 \%$ \\
\hline & 12 & $81 \%$ \\
\hline & 13 & $86 \%$ \\
\hline & 14 & $94 \%$ \\
\hline & 15 & $94 \%$ \\
\hline & 16 & $97 \%$ \\
\hline & $\geq 17$ & $99 \%$ \\
\hline
\end{tabular}

\begin{tabular}{|c|c|c|}
\hline \multicolumn{3}{|c|}{ ABC-GOALS clinic + lab + x-ray } \\
\hline Risk & Total Points & $\begin{array}{l}\text { Probability } \\
\text { of ICU } \\
\text { admission }\end{array}$ \\
\hline \multirow{3}{*}{ కై లి } & 0 & $2 \%$ \\
\hline & 1 & $4 \%$ \\
\hline & 2 & $6 \%$ \\
\hline \multirow{5}{*}{ 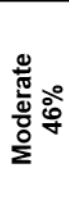 } & 3 & $10 \%$ \\
\hline & 4 & $18 \%$ \\
\hline & 5 & $20 \%$ \\
\hline & 6 & $30 \%$ \\
\hline & 7 & $40 \%$ \\
\hline \multirow{9}{*}{ 홍ㅇํ } & 8 & $56 \%$ \\
\hline & 9 & $58 \%$ \\
\hline & 10 & $71 \%$ \\
\hline & 11 & $84 \%$ \\
\hline & 12 & $88 \%$ \\
\hline & 13 & $93 \%$ \\
\hline & 14 & $96 \%$ \\
\hline & 15 & $97 \%$ \\
\hline & $\geq 16$ & $99 \%$ \\
\hline
\end{tabular}

Abbreviations. ICU, intensive care unit; $L D H$, lactate dehydrogenase; ABG, arterial blood gas analysis; BMI, body mass index in $\mathrm{kg} / \mathrm{m}^{2}$; ULN, upper limit of normality reported by the laboratory; $\mathrm{SaO}_{2} / \mathrm{FiO}_{2}$, ratio of hemoglobin oxygen saturation to fraction of inspired oxygen. 
Figure 3. Receiver operating curves for the ABC-GOALS scores in the development (A) and validation (B) cohorts.

A

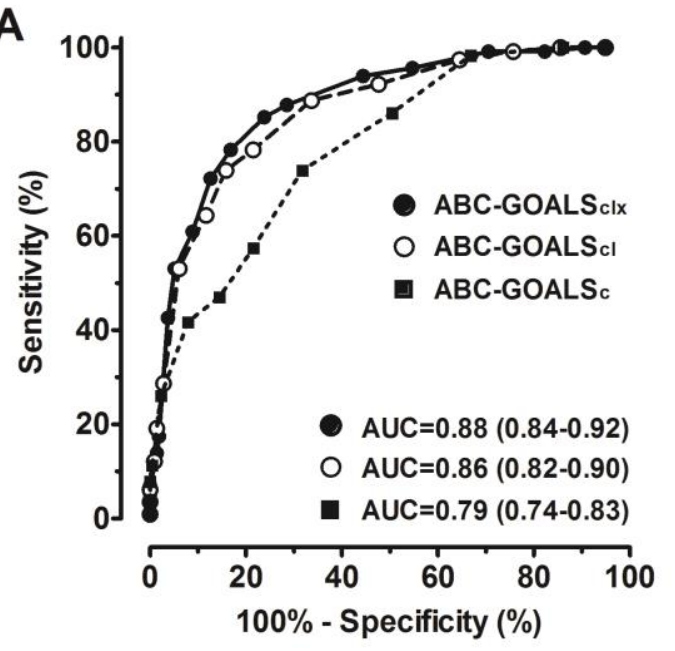

B

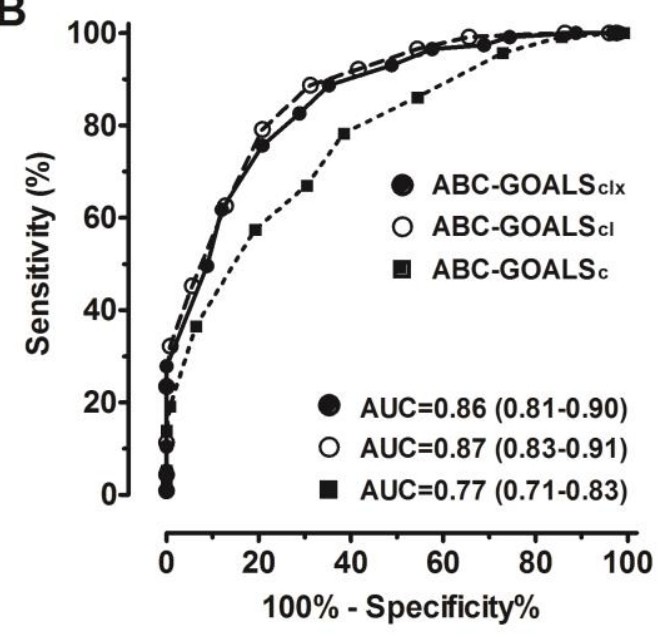




\section{SUPPLEMENTARY MATERIAL}

\section{TABLE OF CONTENTS}

Supplementary Table 1. Characteristics at admission to the emergency department of all the subjects included in the development cohort.

Supplementary Table 2. Variables explored by bivariate logistic regression analysis.

Supplementary Table 3. Characteristics at admission to the emergency department of all the subjects included in the validation cohort.

Supplementary Figure 1. Predicted and observed percentages of patients who required admission to ICU by each point of increment in the ABC-GOALS $(A), A B C-G O A L S_{C l}(B)$ and ABC-GOALS $\mathrm{ClI}_{\mathrm{x}}(\mathrm{C})$ scores. 
medRxiv preprint doi: https://doi.org/10.1101/2020.05.12.20099416; this version posted May 30, 2020. The copyright holder for this preprint (which was not certified by peer review) is the author/funder, who has granted medRxiv a license to display the preprint in perpetuity.

It is made available under a CC-BY-NC-ND 4.0 International license .

Supplementary Table 1. Characteristics at admission to the emergency department of all the subjects included in the derivation cohort.

\begin{tabular}{|c|c|c|c|c|}
\hline & $\begin{array}{c}\text { All patients } \\
n=329\end{array}$ & $\begin{array}{c}\text { Critical Care } \\
n=115\end{array}$ & $\begin{array}{c}\text { General wards } \\
n=214\end{array}$ & p-value \\
\hline Age, years & $49(41-60)$ & $53(43-62)$ & $49(39-59)$ & 0.009 \\
\hline Male gender, $n(\%)$ & $211(64)$ & $88(77)$ & $123(58)$ & $<0.001$ \\
\hline Current/past smoker, n (\%) & $23(7)$ & $10(9)$ & $13(6)$ & 0.497 \\
\hline \multicolumn{5}{|l|}{ Comorbidities } \\
\hline Diabetes mellitus, n (\%) & $80(24)$ & 37 (32) & $43(20)$ & 0.016 \\
\hline Hypertension, n (\%) & $88(27)$ & $33(29)$ & $55(26)$ & 0.602 \\
\hline Obesity, n (\%) & $132(40)$ & $59(51)$ & $73(34)$ & 0.003 \\
\hline CKD, n (\%) & $19(6)$ & $7(6)$ & $12(6)$ & 0.807 \\
\hline None, $n(\%)$ & $100(30)$ & $18(16)$ & $82(38)$ & $<0.001$ \\
\hline Charlson index, points & $1(0-2)$ & $1(0-3)$ & $1(0-2)$ & 0.001 \\
\hline 0 points & $141(43)$ & $36(31)$ & $105(49)$ & 0.002 \\
\hline $1-2$ points & $125(38)$ & $47(41)$ & $78(36)$ & \\
\hline$\geq 3$ points & $63(19)$ & $32(28)$ & $31(15)$ & \\
\hline \multicolumn{5}{|l|}{ Clinical Presentation } \\
\hline Fever, n (\%) & $302(92)$ & $104(90)$ & $198(93)$ & 0.532 \\
\hline Cough, n (\%) & $285(87)$ & $103(90)$ & $182(85)$ & 0.309 \\
\hline Myalgia / arthralgia, $n(\%)$ & $148(45)$ & $40(35)$ & $108(51)$ & 0.007 \\
\hline Sore throat, n (\%) & $100(30)$ & $36(31)$ & $64(30)$ & 0.803 \\
\hline Rhinorrhea, n (\%) & $51(16)$ & $19(17)$ & $32(15)$ & 0.750 \\
\hline Headache, $n(\%)$ & $162(49)$ & $56(49)$ & $106(50)$ & 0.908 \\
\hline Dyspnea, n (\%) & $229(70)$ & $98(85)$ & $131(61)$ & $<0.001$ \\
\hline Diarrhea, n (\%) & $56(17)$ & $21(18)$ & $35(16)$ & 0.759 \\
\hline Anosmia, n (\%) & $17(5)$ & $4(4)$ & $13(6)$ & 0.435 \\
\hline Days with symptoms & $7(5-10)$ & $7(5-9)$ & $8(5-10)$ & 0.595 \\
\hline \multicolumn{5}{|l|}{ Physical examination } \\
\hline Body mass index, $\mathrm{kg} / \mathrm{m}^{2}$ & $29.0(26.5-31.2)$ & $29.6(26.9-33.4)$ & $28.9(26.3-30.6)$ & 0.006 \\
\hline Mean AP, mmHg & $90(83-98)$ & $89(82-97)$ & $91(84-99)$ & 0.152 \\
\hline Systolic AP $<100 \mathrm{mmHg}$ & $16(5)$ & $11(10)$ & $5(2)$ & 0.001 \\
\hline Respiratory rate, per min & $24(21-30)$ & $28(24-36)$ & $24(20-28)$ & $<0.001$ \\
\hline$<24$ per minute & $122(37)$ & $21(18)$ & $101(47)$ & $<0.001$ \\
\hline 24-28 per minute & $116(35)$ & 37 (32) & $79(37)$ & \\
\hline$>28$ per minute & $91(28)$ & $57(50)$ & $34(16)$ & \\
\hline \multicolumn{5}{|l|}{ Laboratory evaluation } \\
\hline Total leukocytes, $x 10^{3} / \mu \mathrm{L}$ & $7.1(5.3-9.5)$ & $9.0(5.8-12.1)$ & $6.7(5.1-8.7)$ & $<0.001$ \\
\hline Neutrophils, $x 10^{3} / \mu \mathrm{L}$ & $5.9(2.8-8.2)$ & $7.7(4.8-10.7)$ & $5.2(3.6-7.1)$ & $<0.001$ \\
\hline Lymphocytes, $\times 10^{3} / \mu \mathrm{L}$ & $0.8(0.6-1.1)$ & $0.7(0.5-1.0)$ & $0.9(0.7-1.1)$ & $<0.001$ \\
\hline Monocytes, $x 10^{3} / \mu \mathrm{L}$ & $0.4(0.3-0.6)$ & $0.4(0.3-0.5)$ & $0.4(0.3-0.6)$ & 0.526 \\
\hline Hemoglobin, g/dL & $15.5(14.4-16.6)$ & $15.5(14.4-16.5)$ & $15.6(14.2-16.6)$ & 0.843 \\
\hline Platelets, $\times 10^{3}$ & $208(165-257)$ & $215(166-266)$ & $206(165-256)$ & 0.515 \\
\hline Total bilirubin, $\mathrm{mg} / \mathrm{dL}$ & $0.55(0.43-0.75)$ & $0.62(0.46-0.84)$ & $0.53(0.43-0.69)$ & 0.005 \\
\hline Direct bilirubin, $\mathrm{mg} / \mathrm{dL}$ & $0.16(0.11-0.22)$ & $0.18(0.14-0.27)$ & $0.14(0.11-0.21)$ & $<0.001$ \\
\hline $\mathrm{ALT}, \mathrm{U} / \mathrm{L}$ & $34.3(23.3-52.7)$ & $37.3(23.9-52.7)$ & 33.7 (22.3-52.6) & 0.574 \\
\hline AST, U/L & $39.3(27.9-57.6)$ & $46.6(33.3-67.8)$ & $36.5(26.5-51.2)$ & $<0.001$ \\
\hline Alkaline phosphatase, $\mathrm{mg} / \mathrm{dL}$ & $83(68-105)$ & $84(70-107)$ & $83(67-103)$ & 0.608 \\
\hline Serum albumin, g/dL & $3.8(3.4-4.1)$ & $3.5(3.2-3.9)$ & $3.9(2.6-4.1)$ & $<0.001$ \\
\hline$<3.5 \mathrm{~g} / \mathrm{dL}, \mathrm{n}(\%)$ & $98(30)$ & $57(50)$ & $41(19)$ & $<0.001$ \\
\hline Serum globulins, g/dL & $3.2(3.0-3.5)$ & $3.3(3.0-3.6)$ & $3.2(2.9-3.5)$ & 0.608 \\
\hline
\end{tabular}


medRxiv preprint doi: https://doi.org/10.1101/2020.05.12.20099416; this version posted May 30, 2020. The copyright holder for this preprint (which was not certified by peer review) is the author/funder, who has granted medRxiv a license to display the preprint in perpetuity.

\begin{tabular}{|c|c|c|c|c|}
\hline Glucose, $\mathrm{mg} / \mathrm{dL}$ & $115(100-147)$ & $138(111-213)$ & $107(97-128)$ & $<0.001$ \\
\hline$>200$ mg/dL, n (\%) & $50(15)$ & $29(25)$ & $21(10)$ & $<0.001$ \\
\hline BUN, mg/dL & $14.0(10.5-19.8)$ & $16.6(12.8-24.0)$ & $12.7(9.7-17.9)$ & $<0.001$ \\
\hline Creatinine, $\mathrm{mg} / \mathrm{dL}$ & $0.93(0.75-1.15)$ & $1.00(0.85-1.24)$ & $0.89(0.72-1.10)$ & $<0.001$ \\
\hline Sodium, $\mathrm{mEq} / \mathrm{L}$ & $135(132-137)$ & $134(132-138)$ & $135(133-137)$ & 0.200 \\
\hline Potassium, mEq/L & $4.0(3.7-4.3)$ & $4.0(3.6-4.3)$ & $4.0(3.7-4.3)$ & 0.823 \\
\hline Chloride, $\mathrm{mEq} / \mathrm{L}$ & $101(98-104)$ & $100(97-104)$ & $102(99-104)$ & 0.042 \\
\hline Total serum $\mathrm{CO}_{2}, \mathrm{mmol} / \mathrm{L}$ & $23.2(21.5-25.0)$ & $22.6(20.8-24.4)$ & $23.4(21.9-25.2)$ & 0.001 \\
\hline Corrected calcium, mg/dL & $8.6(8.5-9.0)$ & $8.6(8.4-8.9)$ & $8.7(8.5-9.0)$ & $<0.001$ \\
\hline Phosphorus, mg/dL & $3.2(2.8-3.7)$ & $3.3(2.7-3.9)$ & $3.2(2.8-3.6)$ & 0.114 \\
\hline Magnesium, mg/dL & $2.1(2.0-2.3)$ & $2.2(2.0-2.4)$ & $2.1(2.0-2.3)$ & 0.076 \\
\hline Creatine kinase, $\mathrm{U} / \mathrm{L}$ & $103(61-222)$ & $142(72-276)$ & $88(57-166)$ & 0.003 \\
\hline Lactate dehydrogenase, $\mathrm{U} / \mathrm{L}$ & $336(259-456)$ & $474(344-578)$ & $288(230-380)$ & $<0.001$ \\
\hline$>$ ULN (271 U/L), n (\%) & $230(70)$ & $106(92)$ & $124(58)$ & $<0.001$ \\
\hline $\mathrm{C}$ reactive protein, $\mathrm{mg} / \mathrm{dL}$ & $12.6(5.4-19.3)$ & $18.3(12.6-25.7)$ & $7.8(3.4-15.6)$ & $<0.001$ \\
\hline Ferritin, $\mathrm{ng} / \mathrm{mL}$ & 506 (254-939) & $740(423-1092)$ & $375(207-784)$ & $<0.001$ \\
\hline Troponin I, pg/mL & $4.6(2.9-8.5)$ & $7.8(4.9-19.4)$ & $3.7(2.6-5.6)$ & $<0.001$ \\
\hline$>$ ULN (20pg/mL), n (\%) & 35 (10.6) & $28(24.3)$ & $7(3.3)$ & $<0.001$ \\
\hline Fibrinogen, $\mathrm{mg} / \mathrm{dL}$ & $604(457-723)$ & $688(542-807)$ & $499(434-678)$ & $<0.001$ \\
\hline D-dimer, ng/mL & $628(398-1072)$ & $761(495-1323)$ & $523(358-958)$ & $<0.001$ \\
\hline \multicolumn{5}{|l|}{ Arterial blood gas analysis } \\
\hline $\mathrm{pH}$ & $7.44(7.42-7.47)$ & $7.44(7.39-7.46)$ & $7.45(7.42-7.47)$ & $<0.001$ \\
\hline Bicarbonate, $\mathrm{mmol} / \mathrm{L}$ & $21.5(19.9-22.9)$ & $21.0(18.6-23.5)$ & $21.6(20.5-22.8)$ & 0.122 \\
\hline Lactate, $\mathrm{mmol} / \mathrm{L}$ & $1.2(0.9-1.6)$ & $1.5(1.0-2.1)$ & $1.1(0.9-1.4)$ & $<0.001$ \\
\hline $\mathrm{PaO}_{2} / \mathrm{FiO}_{2}$ ratio & $247(175-291)$ & $177(107-247)$ & $269(229-305)$ & $<0.001$ \\
\hline $\mathrm{SaO}_{2} / \mathrm{FiO}_{2}$ ratio & $330(211-426)$ & $193(149-325)$ & $410(315-433)$ & $<0.001$ \\
\hline$<300, \mathrm{n}(\%)$ & $124(38)$ & $80(70)$ & $44(21)$ & $<0.001$ \\
\hline \multicolumn{5}{|l|}{ Scores at presentation } \\
\hline NEWS-2, points & $7(5-8)$ & $8(7-10)$ & $6(4-7)$ & $<0.001$ \\
\hline SOFA - $\mathrm{PaO}_{2} / \mathrm{FiO}_{2}$ & $2(2-3)$ & $3(2-4)$ & $2(2-3)$ & $<0.001$ \\
\hline $\mathrm{SOFA}-\mathrm{SaO}_{2} / \mathrm{FiO}_{2}$ & $1(0-2)$ & $2(1-3)$ & $0(0-1)$ & $<0.001$ \\
\hline COVID-GRAM score, points & $116(98-137)$ & $135(115-156)$ & $103(87-125)$ & $<0.001$ \\
\hline CALL score, points & $9(7-11)$ & $10(8-11)$ & $8(7-10)$ & $<0.001$ \\
\hline CURB-65 score, points & $0(0-1)$ & $1(0-2)$ & $0(0-1)$ & $<0.001$ \\
\hline MuLBSTA score, points & $9(5-11)$ & $9(5-11)$ & $7(5-9)$ & $<0.001$ \\
\hline ROX index & $13.6(7.1-18.6)$ & $6.9(4.5-12.9)$ & $16.4(12.3-20.7)$ & $<0.001$ \\
\hline \multicolumn{5}{|l|}{ Chest CT scan } \\
\hline Multi-lobar, n (\%) & $329(100)$ & $115(100)$ & $214(100)$ & 1.000 \\
\hline \multicolumn{5}{|l|}{ Extension, n (\%) } \\
\hline Mild $(\leq 20 \%)$ & $57(17)$ & $3(3)$ & $54(25)$ & $<0.001$ \\
\hline Moderate (21-50\%) & $141(43)$ & $26(23)$ & $115(54)$ & \\
\hline Severe $(>50 \%)$ & $131(40)$ & $86(75)$ & $45(21)$ & \\
\hline
\end{tabular}

Abbreviations. CKD, chronic kidney disease; AP, arterial pressure; ALT, alanine aminotransferase; AST, aspartate aminotransferase; $\mathrm{BUN}$, blood urea nitrogen; $\mathrm{CO}_{2}$, total diluted carbon dioxide; $\mathrm{PaO}_{2} / \mathrm{FiO}_{2}$ ratio, ratio of arterial pressure of oxygen to fraction of inspired oxygen; $\mathrm{SaFiO}_{2} / \mathrm{FiO}_{2}$, ratio of the percentage of hemoglobin saturation by oxygen to fraction of inspired oxygen; NEWS-2, National Early Warning Score 2; SOFA $\mathrm{PaO}_{2} / \mathrm{FiO}_{2}$, Sequential Organ Failure Assessment score with respiratory points obtained by $\mathrm{PaO} 2 / \mathrm{FiO} 2$ ratio; SOFA-SaO $/ \mathrm{FiO}_{2}$, Sequential Organ Failure Assessment score with respiratory points obtained by $\mathrm{SaO}_{2} / \mathrm{FiO}_{2}$; MuLBSTA, Multi-lobar infiltrate, Lymphocyte count, Bacterial co-infection, Smoking history, hypertension, Age $>65$ years score for mortality from viral pneumonia; ROX index, S/F ratio divided by the respiratory rate to predict the risk of intubation in hypoxemic respiratory failure ULN, upper limit of normal. 
medRxiv preprint doi: https://doi.org/10.1101/2020.05.12.20099416; this version posted May 30, 2020. The copyright holder for this preprint (which was not certified by peer review) is the author/funder, who has granted medRxiv a license to display the preprint in perpetuity.

It is made available under a CC-BY-NC-ND 4.0 International license .

Supplementary Table 2. Variables explored by bivariate logistic regression analysis.

\begin{tabular}{|c|c|c|c|}
\hline & OR & $95 \% \mathrm{CI}$ & p-value \\
\hline \multicolumn{4}{|l|}{ Demographics variables } \\
\hline Age, per year & 1.021 & $1.004-1.038$ & $0.015^{\star}$ \\
\hline Age $\geq 50$ years, vs. less & 1.716 & $1.085-2.713$ & $0.021^{*}$ \\
\hline Male gender, vs. female & 2.411 & $1.449-4.013$ & $0.001^{*}$ \\
\hline \multicolumn{4}{|l|}{ Previous medical history } \\
\hline Current or previous smoker, vs. no & 1.473 & $0.625-3.471$ & 0.376 \\
\hline Hypertension, vs. no & 1.163 & $0.701-1.932$ & 0.559 \\
\hline Diabetes mellitus, vs. no & 1.886 & $1.128-3.156$ & $0.016^{\star}$ \\
\hline Chronic kidney disease, vs. no & 1.122 & $0.429-2.935$ & 0.814 \\
\hline Obesity $\left(\mathrm{BMl}>30 \mathrm{~kg} / \mathrm{m}^{2}\right)$, vs. no & 2.035 & $1.282-3.230$ & $0.003^{*}$ \\
\hline No comorbidities, vs. yes & 0.299 & $0.168-0.530$ & $0.000^{*}$ \\
\hline Charlson index, per point & 1.235 & $1.071-1.425$ & $0.004^{*}$ \\
\hline \multicolumn{4}{|l|}{ Charlson index categories } \\
\hline 0 points & 1.000 & reference & reference \\
\hline $1-2$ points & 1.757 & $1.041-2.967$ & 0.035 \\
\hline$\geq 3$ points & 3.011 & $1.616-5.610$ & 0.001 \\
\hline \multicolumn{4}{|l|}{ Clinical presentation variables } \\
\hline Days with symptoms, per day & 1.010 & $0.956-1.066$ & 0.729 \\
\hline Three of more days with symptoms & 3.859 & $0.857-17.38$ & 0.079 \\
\hline Fever, vs. none & 0.764 & $0.342-1.706$ & 0.511 \\
\hline Cough, vs. none & 1.509 & $0.745-3.058$ & $0.253^{*}$ \\
\hline Fatigue/malaise, vs. none & 0.907 & $0.576-1.428$ & 0.673 \\
\hline Mialgia/arthralgia, vs. none & 0.523 & $0.328-0.836$ & $0.007^{*}$ \\
\hline Sore throath, vs. none & 1.068 & $0.654-1.745$ & 0.793 \\
\hline Rinorrhea, vs. none & 1.126 & $0.606-2.091$ & 0.708 \\
\hline Headache, vs. none & 0.967 & $0.615-1.522$ & 0.885 \\
\hline Dyspnea, vs. none & 3.652 & $2.037-6.548$ & $0.000^{*}$ \\
\hline Diarrhea, vs. none & 1.143 & $0.630-2.073$ & 0.661 \\
\hline Anosmia, vs. none & 0.557 & $0.177-1.750$ & 0.316 \\
\hline \multicolumn{4}{|l|}{ Physical examination variables } \\
\hline Mean arterial pressure, per $\mathrm{mmHg}$ & 0.989 & $0.971-1.007$ & 0.233 \\
\hline MAP $<65 \mathrm{mmHg}$, vs. higher & 3.770 & $0.338-42.03$ & 0.281 \\
\hline Systolic arterial pressure, per mmHg & 0.991 & $0.978-1.004$ & 0.184 \\
\hline SAP $<100 \mathrm{mmHg}$, vs. higher & 4.421 & $1.497-13.06$ & $0.007^{\star}$ \\
\hline Diastolic arterial pressure, per $\mathrm{mmHg}$ & 0.991 & $0.973-1.010$ & 0.369 \\
\hline Respiratory rate, per $1 x^{\prime}$ & 1.137 & $1.094-1.183$ & $0.000^{*}$ \\
\hline \multicolumn{4}{|l|}{ Respiratory rate } \\
\hline$<24$ per minute & 1.000 & reference & reference \\
\hline 24-28 per minute & 2.253 & $1.223-4.150$ & 0.009 \\
\hline$>28$ per minute & 8.063 & $4.279-15.19$ & $0.000^{*}$ \\
\hline Body mass index, per $\mathrm{kg} / \mathrm{m}^{2}$ & 1.080 & $1.030-1.132$ & $0.001^{*}$ \\
\hline \multicolumn{4}{|l|}{ Laboratory variables } \\
\hline Total leukocytes, per $1 \times 10^{3}$ & 1.209 & $1.127-1.296$ & $0.000^{*}$ \\
\hline Neutrophils, per $1 \times 10^{3}$ & 1.000 & $1.000-1.000$ & $0.000^{*}$ \\
\hline Lymphocytes, per $1 \times 10^{3}$ & 0.999 & $0.998-1.000$ & $0.001^{*}$ \\
\hline Monocytes, per $1 \times 10^{3}$ & 1.001 & $0.999-1.001$ & 0.596 \\
\hline Hemoglobin, per g/dL & 0.973 & $0.860-1.101$ & 0.666 \\
\hline
\end{tabular}


medRxiv preprint doi: https://doi.org/10.1101/2020.05.12.20099416; this version posted May 30, 2020. The copyright holder for this preprint (which was not certified by peer review) is the author/funder, who has granted medRxiv a license to display the preprint in perpetuity.

\begin{tabular}{|c|c|c|c|}
\hline Platelets, per $1 \times 10^{6}$ & 1.001 & $0.998-1.004$ & 0.559 \\
\hline Total bilirubin, per mg/dL & 1.753 & $0.999-3.076$ & 0.050 \\
\hline Direct bilirubin, per $\mathrm{mg} / \mathrm{dL}$ & 0.963 & $0.806-1.151$ & 0.681 \\
\hline $\mathrm{ALT}$, per U/L & 1.002 & $0.999-1.005$ & 0.256 \\
\hline AST, per U/L & 1.005 & $1.000-1.010$ & $0.033^{*}$ \\
\hline AST $\geq 40 \mathrm{U} / \mathrm{L}, \mathrm{vs}$. lower & 2.310 & $1.452-3.676$ & $0.000^{*}$ \\
\hline Alkaline phosphatase, per mg/dL & 1.001 & $0.996-1.006$ & 0.773 \\
\hline Serum albumin, per $\mathrm{mg} / \mathrm{dL}$ & 0.166 & $0.094-0.294$ & $0.000^{*}$ \\
\hline Serum albumin $<3.5 \mathrm{mg} / \mathrm{dL}$, vs. higher & 4.147 & $2.516-6.834$ & $0.000^{*}$ \\
\hline Serum globulins, per mg/dL & 1.341 & $0.812-2.215$ & 0.252 \\
\hline Glucose, per mg/dL & 1.008 & $1.005-1.012$ & $0.000^{*}$ \\
\hline Glucose $>200 \mathrm{mg} / \mathrm{dL}$, vs. lower & 3.099 & $1.673-5.740$ & $0.000^{*}$ \\
\hline Blood urea nitrogen, per $\mathrm{mg} / \mathrm{dL}$ & 1.048 & $1.023-1.073$ & $0.000^{*}$ \\
\hline Serum creatinine, per $\mathrm{mg} / \mathrm{dL}$ & 1.638 & $1.003-2.676$ & $0.048^{*}$ \\
\hline Sodium, per $\mathrm{mEq} / \mathrm{L}$ & 0.967 & $0.914-1.024$ & 0.253 \\
\hline Potasium, per mEq/L & 1.124 & $0.853-1.481$ & 0.405 \\
\hline Chloride, per $\mathrm{mEq} / \mathrm{L}$ & 0.945 & $0.894-0.997$ & $0.040^{*}$ \\
\hline Total $\mathrm{CO}_{2}$, per $\mathrm{mmol} / \mathrm{L}$ & 0.873 & $0.803-0.948$ & $0.001^{*}$ \\
\hline Corrected calcium, per mg/dL & 1.008 & $0.851-1.194$ & 0.927 \\
\hline Phosphorus, per mg/dL & 1.452 & $1.091-1.931$ & $0.011^{*}$ \\
\hline Magnesium per $\mathrm{mg} / \mathrm{dL}$ & 1.821 & $0.875-3.793$ & 0.109 \\
\hline Creatine kinase, per U/L & 1.001 & $1.000-1.002$ & 0.067 \\
\hline Lactate dehydrogenase, per U/L & 1.006 & $1.004-1.07$ & $0.000^{*}$ \\
\hline$\geq$ upper limit of normal, vs. lower & 8.548 & $4.109-17.79$ & $0.000^{*}$ \\
\hline C-reactive protein, per $\mathrm{mg} / \mathrm{dL}$ & 1.114 & $1.082-1.148$ & $0.000^{*}$ \\
\hline$\geq 5 \mathrm{mg} / \mathrm{dL}$, vs. lower & 29.252 & $7.026-121.8$ & $0.000^{*}$ \\
\hline$\geq 10 \mathrm{mg} / \mathrm{dL}$, vs. lower & 7.942 & $4.438-14.215$ & $0.000^{*}$ \\
\hline Ferritin, per $\mathrm{ng} / \mathrm{mL}$ & 1.001 & $1.000-1.001$ & $0.000^{*}$ \\
\hline$\geq 400 \mathrm{ng} / \mathrm{mL}$, vs. lower & 3.579 & $2.154-5.947$ & $0.000^{*}$ \\
\hline Troponin I, per pg/mL & 1.006 & $1.000-1.012$ & $0.047^{\star}$ \\
\hline zupper limit of normal, vs. lower & 9.471 & $3.987-22.501$ & $0.000^{*}$ \\
\hline Fibrinogen, per $\mathrm{mg} / \mathrm{dL}$ & 1.004 & $1.002-1.005$ & $0.000^{*}$ \\
\hline$\geq 500 \mathrm{ng} / \mathrm{mL}$, vs. lower & 3.249 & $1.963-5.376$ & $0.000^{*}$ \\
\hline $\mathrm{D}$ dimer, per $\mathrm{ng} / \mathrm{mL}$ & 1.000 & $1.000-1.000$ & $0.036^{\star}$ \\
\hline$\geq 500 \mathrm{ng} / \mathrm{mL}$, vs. lower & 2.620 & $1.589-4.318$ & $0.000^{*}$ \\
\hline \multicolumn{4}{|l|}{ Arterial blood gas analysis } \\
\hline $\mathrm{pH}$, per unit & 0.000 & $0.000-0.003$ & $0.000^{*}$ \\
\hline Bicarbonate, per mmol/L & 0.948 & $0.880-1.021$ & 0.948 \\
\hline Lactate, per $\mathrm{mmol} / \mathrm{L}$ & 2.352 & $1.620-3.415$ & $0.000^{*}$ \\
\hline $\mathrm{P} / \mathrm{F}$ ratio, per unit & 0.989 & $0.985-0.992$ & $0.000^{*}$ \\
\hline S/F ratio, per unit & 0.990 & $0.988-0.992$ & $0.000^{*}$ \\
\hline S/F ratio $<300$, vs. higher & 8.831 & $5.264-14.815$ & $0.000^{*}$ \\
\hline \multicolumn{4}{|l|}{ Scores } \\
\hline NEWS-2, per point & 1.604 & $1.409-1.826$ & $0.000^{*}$ \\
\hline $\mathrm{SOFA}-\mathrm{PaO}_{2} / \mathrm{FiO}_{2}$, per point & 1.911 & $1.551-2.355$ & $0.000^{*}$ \\
\hline $\mathrm{SOFA}-\mathrm{SaO}_{2} / \mathrm{FiO}_{2}$, per point & 2.090 & $1.711-2.551$ & $0.000^{*}$ \\
\hline COVID-GRAM score, per point & 1.037 & $1.027-1.047$ & $0.000^{*}$ \\
\hline CALL score, per point & 1.483 & $1.311-1.677$ & $0.000^{*}$ \\
\hline CURB-65, per point & 2.409 & $1.831-3.170$ & $0.000^{*}$ \\
\hline ROX index, per point & 0.822 & $0.785-0.862$ & $0.000^{*}$ \\
\hline MuLBSTA score, per point & 1.200 & $1.099-1.310$ & $0.000^{*}$ \\
\hline
\end{tabular}


medRxiv preprint doi: https://doi.org/10.1101/2020.05.12.20099416; this version posted May 30, 2020. The copyright holder for this preprint

(which was not certified by peer review) is the author/funder, who has granted medRxiv a license to display the preprint in perpetuity.

It is made available under a CC-BY-NC-ND 4.0 International license .

\begin{tabular}{|l|c|c|c|}
\hline Chest CT scan & & & \\
\hline Pneumonia extension & & & \\
\hline Mild-moderate $(<50 \%)$ & 1.000 & reference & Reference \\
\hline Severe $(>50 \%)$ & 11.137 & $6.529-18.99$ & $<0.001$ \\
\hline
\end{tabular}

Abbreviations. BMI, body mass index; ALT, alanine aminotransferase; AST, aspartate aminotransferase; P/F ratio, ratio of arterial pressure of oxygen to fraction of inspired oxygen; S/F ratio, ratio of oxygen hemoglobin saturation to fraction of inspired oxygen; NEWS-2, National Early Warning Score 2; SOFA - $\mathrm{PaO}_{2} / \mathrm{FiO}_{2}$, Sequential Organ Failure Assessment score with respiratory points obtained by $\mathrm{PaO} 2 / \mathrm{FiO} 2$ ratio; SOFA$\mathrm{SaO}_{2} / \mathrm{FiO}_{2}$, Sequential Organ Failure Assessment score with respiratory points obtained by $\mathrm{SaO}_{2} / \mathrm{FiO}_{2}$, MuLBSTA, Multi-lobar infiltrate, Lymphocyte count, Bacterial co-infection, Smoking history, hypertension, Age $>65$ years score for mortality from viral pneumonia; ROX index, S/F ratio divided by the respiratory rate to predict the risk of intubation in hypoxemic respiratory failure. 
medRxiv preprint doi: https://doi.org/10.1101/2020.05.12.20099416; this version posted May 30, 2020. The copyright holder for this preprint (which was not certified by peer review) is the author/funder, who has granted medRxiv a license to display the preprint in perpetuity.

It is made available under a CC-BY-NC-ND 4.0 International license .

Supplementary Table 3. Characteristics at admission to the emergency department of all the subjects included in the validation cohort.

\begin{tabular}{|c|c|c|c|c|}
\hline & $\begin{array}{c}\text { All patients } \\
n=240\end{array}$ & $\begin{array}{c}\text { Critical Care } \\
n=115\end{array}$ & $\begin{array}{c}\text { General wards } \\
\qquad n=125\end{array}$ & p-value \\
\hline Age, years & $52(43-60)$ & $55(46-65)$ & $50(42-58)$ & 0.001 \\
\hline Male gender, $\mathrm{n}(\%)$ & $166(69)$ & $86(75)$ & $80(74)$ & 0.071 \\
\hline Current/past smoker, n (\%) & $36(15)$ & $13(11)$ & $23(18)$ & 0.124 \\
\hline \multicolumn{5}{|l|}{ Comorbidities } \\
\hline Diabetes mellitus, n (\%) & $78(33)$ & $47(41)$ & $31(25)$ & 0.008 \\
\hline Hypertension, n (\%) & $74(31)$ & $39(34)$ & $35(28)$ & 0.322 \\
\hline Obesity, n (\%) & $127(53)$ & $64(56)$ & $63(50)$ & 0.415 \\
\hline CKD, n (\%) & $12(5)$ & $5(4)$ & $7(6)$ & 0.657 \\
\hline None, $n(\%)$ & $50(21)$ & $19(17)$ & $31(25)$ & 0.115 \\
\hline \multicolumn{5}{|l|}{ Charlson index, points } \\
\hline 0 points & $80(33)$ & $29(25)$ & $51(41)$ & $<0.001$ \\
\hline $1-2$ points & $11(46)$ & $48(42)$ & $63(50)$ & \\
\hline$\geq 3$ points & $49(21)$ & $38(33)$ & $11(9)$ & \\
\hline \multicolumn{5}{|l|}{ Clinical Presentation } \\
\hline Fever, n (\%) & $201(84)$ & $94(82)$ & $107(86)$ & 0.418 \\
\hline Cough, n (\%) & $191(80)$ & $94(82)$ & $97(78)$ & 0.427 \\
\hline Myalgia / arthralgia, n (\%) & $145(60)$ & $23(20)$ & $48(38)$ & 0.002 \\
\hline Sore throat, n (\%) & $55(23)$ & $27(24)$ & $28(22)$ & 0.843 \\
\hline Rhinorrhea, n (\%) & $32(13)$ & $16(14)$ & $16(13)$ & 0.800 \\
\hline Headache, $\mathrm{n}(\%)$ & $121(50)$ & $52(45)$ & $69(55)$ & 0.122 \\
\hline Dyspnea, n (\%) & $211(88)$ & $108(94)$ & $103(82)$ & 0.006 \\
\hline Diarrhea, $n$ (\%) & $42(18)$ & $13(11)$ & $29(23)$ & 0.015 \\
\hline Anosmia, $\mathrm{n}(\%)$ & $18(8)$ & $7(6)$ & $11(9)$ & 0.425 \\
\hline Days with symptoms & $8(5-10)$ & $7(5-10)$ & $8(5-11)$ & 0.431 \\
\hline \multicolumn{5}{|l|}{ Physical examination } \\
\hline Body mass index, $\mathrm{kg} / \mathrm{m}^{2}$ & $30.1(26.7-33.9)$ & $30.1(26.6-34.4)$ & $29.8(26.8-33.8)$ & $<0.001$ \\
\hline Mean AP, mmHg & $92(83-97)$ & $90(78-97)$ & $93(87-100)$ & 0.011 \\
\hline Systolic AP $<100 \mathrm{mmHg}$ & $10(4)$ & $9(8)$ & $1(1)$ & $<0.001$ \\
\hline \multicolumn{5}{|l|}{ Respiratory rate, per min } \\
\hline$<24$ per minute & $48(20)$ & $10(9)$ & $38(30)$ & $<0.001$ \\
\hline 24-28 per minute & $65(27)$ & $24(21)$ & $41(33)$ & \\
\hline$>28$ per minute & $127(53)$ & $81(70)$ & $46(37)$ & \\
\hline \multicolumn{5}{|l|}{ Laboratory evaluation } \\
\hline Total leukocytes, $\times 10^{3} / \mu \mathrm{L}$ & $8.6(6.5-12.7)$ & $9.9(7.2-14.4)$ & $8.0(5.7-10.7)$ & $<0.001$ \\
\hline Neutrophils, $x 10^{3} / \mu \mathrm{L}$ & $7.3(5.4-10.9)$ & $8.2(6.2-13.1)$ & $6.4(4.8-8.8)$ & $<0.001$ \\
\hline Lymphocytes, $\times 10^{3} / \mu \mathrm{L}$ & $0.8(0.5-1.0)$ & $0.7(0.5-1.0)$ & $0.8(0.6-1.1)$ & 0.018 \\
\hline Monocytes, $x 10^{3} / \mu \mathrm{L}$ & $0.4(0.3-0.6)$ & $0.4(0.3-0.6)$ & $0.4(0.3-0.6)$ & 0.795 \\
\hline Hemoglobin, g/dL & $15.5(14.3-16.3)$ & $15.1(14.2-16.3)$ & $15.7(14.4-16.4)$ & 0.255 \\
\hline Platelets, $\times 10^{3}$ & $235(182-307)$ & $239(190-307)$ & $234(175-308)$ & 0.447 \\
\hline Total bilirubin, mg/dL & $0.6(0.5-0.9)$ & $0.7(0.5-1.0)$ & $0.6(0.5-0.8)$ & 0.038 \\
\hline Direct bilirubin, mg/dL & $0.2(0.1-0.3)$ & $0.2(0.1-0.3)$ & $0.2(0.1-0.2)$ & 0.008 \\
\hline ALT, U/L & $38(25-60)$ & $44(27-62)$ & $34(23-52)$ & 0.008 \\
\hline AST, U/L & $44(32-64)$ & $49(39-65)$ & $40(27-60)$ & 0.001 \\
\hline Alkaline phosphatase, mg/dL & $93(73-120)$ & $97(76-131)$ & $87(71-112)$ & 0.068 \\
\hline Serum albumin, g/dL & $3.6(3.3-3.9)$ & $3.4(3.1-3.7)$ & $3.8(3.5-4.0)$ & $<0.001$ \\
\hline$<3.5 \mathrm{~g} / \mathrm{dL}, \mathrm{n}(\%)$ & $103(43)$ & $69(60)$ & $34(27)$ & $<0.001$ \\
\hline Serum globulins, g/dL & $3.4(3.1-3.6)$ & $3.4(3.1-3.6)$ & $3.4(3.2-3.7)$ & 0.991 \\
\hline
\end{tabular}


medRxiv preprint doi: https://doi.org/10.1101/2020.05.12.20099416; this version posted May 30, 2020. The copyright holder for this preprint (which was not certified by peer review) is the author/funder, who has granted medRxiv a license to display the preprint in perpetuity. It is made available under a CC-BY-NC-ND 4.0 International license .

\begin{tabular}{|c|c|c|c|c|}
\hline Glucose, mg/dL & $132(107-182)$ & $153(118-230)$ & $119(104-145)$ & $<0.001$ \\
\hline$>200 \mathrm{mg} / \mathrm{dL}, \mathrm{n}(\%)$ & $51(21)$ & $36(31)$ & $15(12)$ & $<0.001$ \\
\hline $\mathrm{BUN}, \mathrm{mg} / \mathrm{dL}$ & $18(12-26)$ & $21(15-30)$ & $15(11-19)$ & $<0.001$ \\
\hline Creatinine, $\mathrm{mg} / \mathrm{dL}$ & $1.0(0.8-1.2)$ & $1.0(0.8-1.3)$ & $0.9(0.8-1.1)$ & 0.006 \\
\hline Sodium, $\mathrm{mEq} / \mathrm{L}$ & $135(133-138)$ & $134(132-137)$ & $135(133-138)$ & 0.038 \\
\hline Potassium, mEq/L & $4.1(3.8-4.5)$ & $4.1(3.9-4.6)$ & $4.1(3.8-4.4)$ & 0.166 \\
\hline Chloride, mEq/L & $101(98-103)$ & $101(97-104)$ & $101(98-103)$ & 0.475 \\
\hline Total serum $\mathrm{CO}_{2}, \mathrm{mmol} / \mathrm{L}$ & $22.8(20.8-24.7)$ & $22.1(19.8-24.4)$ & $23.3(21.2-25.6)$ & 0.001 \\
\hline Corrected calcium, mg/dL & $8.7(8.5-9.0)$ & $8.7(8.5-9.0)$ & $8.7(8.5-9.0)$ & 0.879 \\
\hline Phosphorus, mg/dL & $3.3(2.9-3.8)$ & $3.3(2.9-3.9)$ & $3.2(2.9-3.7)$ & 0.453 \\
\hline Magnesium, mg/dL & $2.2(2.0-2.4)$ & $2.3(2.1-2.4)$ & $2.2(2.0-2.4)$ & 0.028 \\
\hline Creatine kinase, $\mathrm{U} / \mathrm{L}$ & $109(60-242)$ & $143(72-242)$ & $96(59-243)$ & 0.011 \\
\hline Lactate dehydrogenase, $\mathrm{U} / \mathrm{L}$ & $413(317-548)$ & $518(403-586)$ & $342(277-429)$ & $<0.001$ \\
\hline$>$ ULN (271 U/L), n (\%) & $206(86)$ & $110(96)$ & $96(77)$ & $<0.001$ \\
\hline $\mathrm{C}$ reactive protein, $\mathrm{mg} / \mathrm{dL}$ & $17.3(10.7-25.7)$ & $20.0(13.8-29.3)$ & $14.3(9.0-20.0)$ & $<0.001$ \\
\hline Ferritin, $\mathrm{ng} / \mathrm{mL}$ & 747 (399-1134) & $812(514-1275)$ & $712(345-1056)$ & 0.006 \\
\hline Troponin I, pg/mL & $6.2(3.8-14.4)$ & $10.5(5.4-49.2)$ & $4.6(3.0-7.2)$ & $<0.001$ \\
\hline$>\operatorname{ULN}(20 \mathrm{pg} / \mathrm{mL}), \mathrm{n}(\%)$ & $51(21)$ & $39(34)$ & $12(10)$ & $<0.001$ \\
\hline Fibrinogen, $\mathrm{mg} / \mathrm{dL}$ & $735(616-887)$ & $770(648-934)$ & $703(554-858)$ & 0.002 \\
\hline D-dimer, $\mathrm{ng} / \mathrm{mL}$ & $849(525-1396)$ & $1088(661-1967)$ & $715(437-1092)$ & $<0.001$ \\
\hline \multicolumn{5}{|l|}{ Arterial blood gas analysis } \\
\hline $\mathrm{pH}$ & $7.43(7.40-7.47)$ & $7.42(7.38-7.46)$ & $7.44(7.42-7.47)$ & 0.001 \\
\hline Bicarbonate, $\mathrm{mmol} / \mathrm{L}$ & $21.4(19.6-23.1)$ & $21(19-23)$ & $22(20-23)$ & 0.014 \\
\hline Lactate, $\mathrm{mmol} / \mathrm{L}$ & $1.5(1.2-2.1)$ & $1.8(1.4-2.5)$ & $1.3(1.0-1.7)$ & $<0.001$ \\
\hline $\mathrm{PaO}_{2} / \mathrm{FiO}_{2}$ ratio & $197(122-260)$ & $133(98-199)$ & $241(193-279)$ & $<0.001$ \\
\hline $\mathrm{SaO}_{2} / \mathrm{FiO}_{2}$ ratio & $258(158-371)$ & $159(148-252)$ & $330(252-422)$ & $<0.001$ \\
\hline$<300, \mathrm{n}(\%)$ & $142(59)$ & $99(86)$ & $43(34)$ & $<0.001$ \\
\hline \multicolumn{5}{|l|}{ Scores at presentation } \\
\hline NEWS-2, points & $8(6-9)$ & $8(7-9)$ & $7(6-9)$ & $<0.001$ \\
\hline SOFA - $\mathrm{PaO}_{2} / \mathrm{FiO}_{2}$ & $3(2-4)$ & $4(3-4)$ & $3(2-3)$ & $<0.001$ \\
\hline SOFA - $\mathrm{SaO}_{2} / \mathrm{FiO}_{2}$ & $2(0-3)$ & $2(2-3)$ & $1(0-2)$ & $<0.001$ \\
\hline COVID-GRAM score, points & $129(113-149)$ & $140(126-162)$ & $118(104-134)$ & $<0.001$ \\
\hline CALL score, points & $10(8-11)$ & $10(9-11)$ & $9(8-10)$ & $<0.001$ \\
\hline CURB-65 score, points & $1(0-2)$ & $2(1-2)$ & $1(0-1)$ & $<0.001$ \\
\hline MuLBSTA score, points & $9(7-11)$ & $9(7-11)$ & $9(5-11)$ & $<0.001$ \\
\hline ROX index & $8.6(4.9-13.6)$ & $5.4(4.0-8.1)$ & $13.1(8.5-17.2)$ & $<0.001$ \\
\hline \multicolumn{5}{|l|}{ Chest CT scan } \\
\hline Multi-lobar, n (\%) & $240(100)$ & $115(100)$ & $125(100)$ & 1.000 \\
\hline \multicolumn{5}{|l|}{ Extension, n (\%) } \\
\hline Mild $(\leq 20 \%)$ & $6(3)$ & $0(0)$ & $6(5)$ & $<0.001$ \\
\hline Moderate (21-50\%) & $89(37)$ & $23(20)$ & $66(53)$ & \\
\hline Severe $(>50 \%)$ & $145(60)$ & $92(80)$ & $53(42)$ & \\
\hline
\end{tabular}

Abbreviations. CKD, chronic kidney disease; AP, arterial pressure; ALT, alanine aminotransferase; AST, aspartate aminotransferase; $\mathrm{BUN}$, blood urea nitrogen; $\mathrm{CO}_{2}$, total diluted carbon dioxide; $\mathrm{PaO}_{2} / \mathrm{FiO}_{2}$ ratio, ratio of arterial pressure of oxygen to fraction of inspired oxygen; $\mathrm{SaFiO}_{2} / \mathrm{FiO}_{2}$, ratio of the percentage of hemoglobin saturation by oxygen to fraction of inspired oxygen; NEWS-2, National Early Warning Score 2; SOFA $\mathrm{PaO}_{2} / \mathrm{FiO}_{2}$, Sequential Organ Failure Assessment score with respiratory points obtained by $\mathrm{PaO} 2 / \mathrm{FiO} 2$ ratio; SOFA-SaO $/ \mathrm{FiO}_{2}$, Sequential Organ Failure Assessment score with respiratory points obtained by $\mathrm{SaO}_{2} / \mathrm{FiO}_{2}$; MuLBSTA, Multi-lobar infiltrate, Lymphocyte count, Bacterial co-infection, Smoking history, hypertension, Age $>65$ years score for mortality from viral pneumonia; ROX index, S/F ratio divided by the respiratory rate to predict the risk of intubation in hypoxemic respiratory failure ULN, upper limit of normal. 
medRxiv preprint doi: https://doi.org/10.1101/2020.05.12.20099416; this version posted May 30, 2020. The copyright holder for this preprint (which was not certified by peer review) is the author/funder, who has granted medRxiv a license to display the preprint in perpetuity.

It is made available under a CC-BY-NC-ND 4.0 International license .

Supplementary Figure 1. Predicted and observed percentages of patients who required admission to ICU by each point of increment in the ABC-GOALS ${ }_{c}(A), A B C-G O A L S_{c l}(B)$ and ABC-GOALS ${ }_{\mathrm{clx}}(\mathrm{C})$ scores.

A

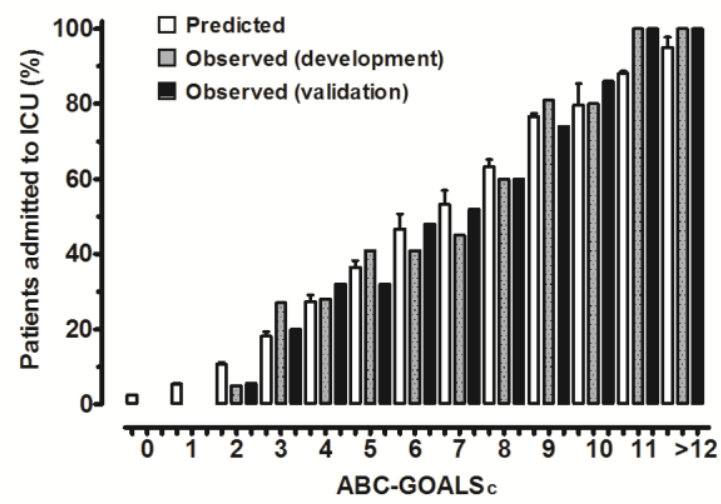

B

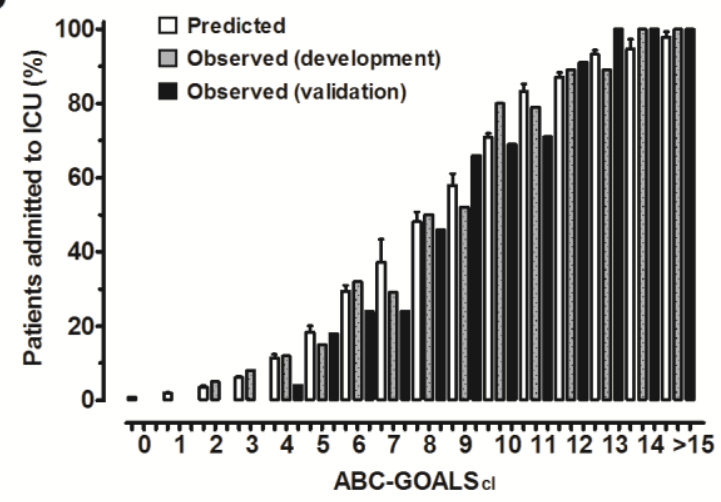

C

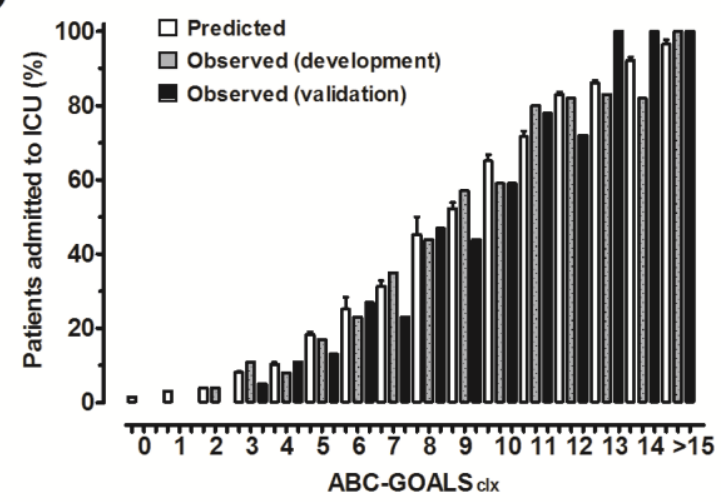

